\title{
Population characteristics of a recovering US Virgin Islands red hind spawning aggregation following protection
}

\author{
Richard S. Nemeth* \\ Center for Marine and Environmental Studies, University of the Virgin Islands, 2 John Brewer's Bay, St. Thomas, \\ US Virgin Islands 00802-9990, USA
}

\begin{abstract}
Many species of groupers form spawning aggregations, dramatic events where 100s to 1000s of individuals gather annually at specific locations for reproduction. Spawning aggregations are often targeted by local fishermen, making them extremely vulnerable to over fishing. The Red Hind Bank Marine Conservation District located in St. Thomas, United States Virgin Islands, was closed seasonally in 1990 and closed permanently in 1999 to protect an important red hind Epinephelus guttatus spawning site. This study provides some of the first information on the population response of a spawning aggregation located within a marine protected area. Tag-and-release fishing and fish transects were used to evaluate population characteristics and habitat utilization patterns of a red hind spawning aggregation between 1999 and 2004. Compared with studies conducted before the permanent closure, the average size of red hind increased mostly during the seasonal closure period (10 cm over $12 \mathrm{yr}$ ), but the maximum total length of male red hind increased by nearly $7 \mathrm{~cm}$ following permanent closure. Average density and biomass of spawning red hind increased by over $60 \%$ following permanent closure whereas maximum spawning density more than doubled. Information from tag returns indicated that red hind departed the protected area following spawning and migrated 6 to $33 \mathrm{~km}$ to a ca. $500 \mathrm{~km}^{2}$ area. Protection of the spawning aggregation site may have also contributed to an overall increase in the size of red hind caught in the commercial fishery, thus increasing the value of the grouper fishery for local fishermen.
\end{abstract}

KEY WORDS: Marine protected areas $\cdot$ Fishery management $\cdot$ Serranidae $\cdot$ Caribbean $\cdot$ Habitat use Fish migration · Tag-and-release $\cdot$ Size frequency

\section{INTRODUCTION}

Over the past $20 \mathrm{yr}$, many island nations throughout the Caribbean, including the United States Virgin Islands (USVI), have witnessed steady declines in catches of commercially important marine fishes (Council 1985, Roberts 1997). Sustained fishing pressure in multi-species tropical fisheries can cause progressive changes in fish communities as well as shifts in the size structure of targeted populations (Munro 1996). These effects are accelerated when fishers target the large, annual spawning aggregations formed at predictable locations by many species of tropical reef fishes, especially snappers and groupers (Johannes 1978, 1989, Olsen \& LaPlace 1978, Colin et al. 1987,
Beets \& Friedlander 1992, Sadovy et al. 1994a,b, Beets \& Friedlander 1997, 1999). Since spawning aggregations are the primary source of larval production and may replenish the local fishery through larval retention and recruitment (Roberts 1996, Sadovy 1996), overfishing of spawning aggregations may dramatically reduce the local abundance of these species causing population-level impacts (Claro \& Lindeman 2003). Where once snappers and groupers made up the bulk of the catch of the commercial fishery, landings throughout the Caribbean are now dominated by herbivorous species such as parrot fishes and surgeon fishes (Tobias 1997).

Marine protected areas (MPAs), which prohibit all fishing activity, are beginning to be recognized as 
alternative marine conservation management tools implemented to attain sustainable fish populations by maintaining ecosystem biodiversity, conserving genetic diversity, enhancing spawning stock, increasing productivity and reproductive output and protecting habitat structure (reviews by Allison et al. 1998, Bohnsack 1998, Appeldoorn \& Lindeman 2003). Most MPAs, regardless of size, seem to have a relatively rapid (1 to $3 \mathrm{yr}$ ) and positive effect on the density, biomass, size and diversity of organisms within the closed area compared to outside or after reserve formation versus before (Halpern \& Warner 2002, review). Although these reviews showed the positive effects of MPA's on various biological measures inside reserves, most existing reserves may be too small to benefit regional fisheries (i.e. beyond the area immediately adjacent to reserve boundaries) and have a limited ability to permanently protect populations such as groupers and snappers that engage in long-distance migrations (McClanahan \& Kaunda-Arara 1996, Bohnsack 1998, McClanahan \& Mangi 2000, Roberts et al. 2001). However, well-placed MPAs can protect particularly vulnerable periods during a species life history such as temporary residence in nursery, feeding and spawning habitats (Kramer \& Chapman 1999).

The life-history characteristics of groupers forming spawning aggregations render them particularly vulnerable to even moderate fishing mortality. For example, most species of Caribbean groupers are protogynous hermaphrodites that form size-structured spawning aggregations comprised of small females and large terminal-phase males (Domeier \& Colin 1997). Intensive fishing pressure on grouper spawning aggregations can severely reduce overall biomass (Alcala 1988, Roberts 1995), decrease size and age at sexual maturity due to selective removal of the large reproductive males (PDT 1990), and drastically alter the sex ratio and disrupt the social structure necessary for successful reproduction (Colin et al. 1987, Shapiro et al. 1994, Beets \& Friedlander 1999). Seasonal and permanent closures have been enacted to protect the biological integrity of single-species fish spawning aggregations (Sadovy 1994, Bohnsack 1996, Domeier \& Colin 1997). Unfortunately, area closures can take years to establish and, when finally implemented, overfishing has usually caused serious damage to the spawning populations and either collapse of the aggregation has already occurred or recovery is very slow (Olsen \& LaPlace 1978, Claro et al. 2001).

Negative impacts of fishing on grouper and snapper spawning aggregations have been documented throughout the Caribbean, e.g. Belize (Heyman et al. 2001, Sala et al. 2001), Bermuda (Luckhurst 1996), Cuba (Claro \& Lindeman 2003), Florida Keys (Lindeman et al. 2000), Mexico (Aguilar-Perera \& Aguilar-
Davila 1996), Puerto Rico (Shapiro et al. 1993, Sadovy et al. 1994a,b), and the US Virgin Islands (Olsen \& LaPlace 1978). Few empirical examples exist, however, of a permanent marine protected area facilitating the recovery of a spawning aggregation. The primary objective of this paper was to report on the population response of a red hind spawning aggregation following establishment of a MPA.

In the United States Virgin Islands, intensive fishing throughout the 1970s and early 1980s eliminated several Nassau Epinephelus striatus and yellow-fin Mycteroperca venenosa grouper spawning aggregations (Olsen \& LaPlace 1978). After the population collapse of these 2 species, commercial fishermen began targeting the red hind E. guttatus, a smaller serranid that also forms spawning aggregations (Beets \& Friedlander 1999). Red hind contributed 70 to $99 \%$ of the total catch of fin fish landed in the Virgin Islands between 1987 and 1992 (Cummings et al. 1997). By the late 1980 s an evaluation of the red hind stock around St. Thomas showed dramatic decreases in average length and an extremely skewed female-to-male sex ratio $(15: 1)$ of the spawning population (Beets \& Friedlander 1992), suggesting a disproportional harvest of large males (Sadovy \& Figuerola 1992). In an effort to avert another fishery collapse, a 3 mo seasonal closure, which encompassed the December through February spawning season, was implemented in November 1990 on the island of St. Thomas to protect the annual spawning aggregation of red hind. This spawning aggregation site, known locally as the Red Hind Bank, is located along the shelf edge $12 \mathrm{~km}$ south of St. Thomas and includes the site of an extirpated Nassau grouper spawning aggregation (Beets \& Friedlander 1999).

After several years of seasonal protection the red hind spawning population on St. Thomas began to show signs of recovery. By 1997 the average size of spawning adults had increased by $7 \mathrm{~cm}$ in length and the sex ratio had shifted to 4 females per male (Beets \& Friedlander 1999). The potential value of this site to the local fishery led the Caribbean Fisheries Management Council, with the support of local fishermen, to recommend the Red Hind Bank as a permanent 'Marine Conservation District' (MCD). In December 1999 the Red Hind Bank MCD was established as the first no-take fishery reserve in the USVI, and protected $41 \mathrm{~km}^{2}$ of deep coral reefs (33 to $45 \mathrm{~m}$ ) along the southern shelf of the insular platform. The creation of the MCD, which represents approximately $1.5 \%$ of the fishing grounds within the Virgin Islands (Bohnsack 2000), reflected a shift in management from a single-species approach (seasonal closure) to an ecosystem-level approach that protected not only key species of commercial importance but also provided protection of a large area of critical fish habitat (Allison et al. 1998). 
However, because red hind migrate to their spawning aggregation sites on an annual basis, it was unclear if the permanent closure and protection of critical fish spawning habitat would have additional positive effects on the spawning population (as described by Beets \& Friedlander 1999) or if it would enhance the local fishery. The primary objectives of the research presented in this paper were to (1) characterize the red hind spawning aggregation and document changes in size structure, density and biomass of the spawning population following establishment of the MCD, (2) compare these parameters with published data on the spawning population during seasonal closure, (3) characterize habitat use and movement patterns of the spawning population and (4) identify the source population of the St. Thomas spawning aggregation and determine if fish leaving the spawning aggregation contributed to the local fishery. Research by Shapiro (1987) and Sadovy et al. (1994b) indicated that, following spawning, females migrate to shallower inshore areas while the larger males remain on the deeper offshore reefs. Based on these gender-specific migratory patterns, it was hypothesized that the permanent closure would have additional positive effects, relative to the seasonal closure, on the size structure and density of the red hind spawning population since a proportion of the spawning population, including larger males, would remain within the MCD and not be caught by the commercial fishery. Moreover, since red hind are known to disperse 10 to $18 \mathrm{~km}$ from the spawning aggregation (Colin et al. 1987, Sadovy et al. 1992), it was predicted that some of the red hind from the St. Thomas spawning aggregation would migrate beyond the boundaries of the MCD to be caught by the local fishery. This paper reports on the conservation management implications of protecting a red hind spawning aggregation site and evaluates the benefits to the local fishery.

\section{MATERIALS AND METHODS}

Study site and species. The MCD is $12 \mathrm{~km}$ south of St. Thomas, USVI, encompasses $41 \mathrm{~km}^{2}$ of shelf-edge reef, and contains at least 1 primary red hind spawning aggregation site (Beets \& Friedlander 1999). The primary spawning aggregation site extends from $18^{\circ} 12.20^{\prime} \mathrm{N}, 65^{\circ} 0.10^{\prime} \mathrm{W}$ to $18^{\circ} 12.20 \mathrm{~N}, 65^{\circ} 0.40 \mathrm{~W}$ and is located within the MCD (Fig. 1). Depth at the spawning aggregation site ranged from 33 to $45 \mathrm{~m}$. Large

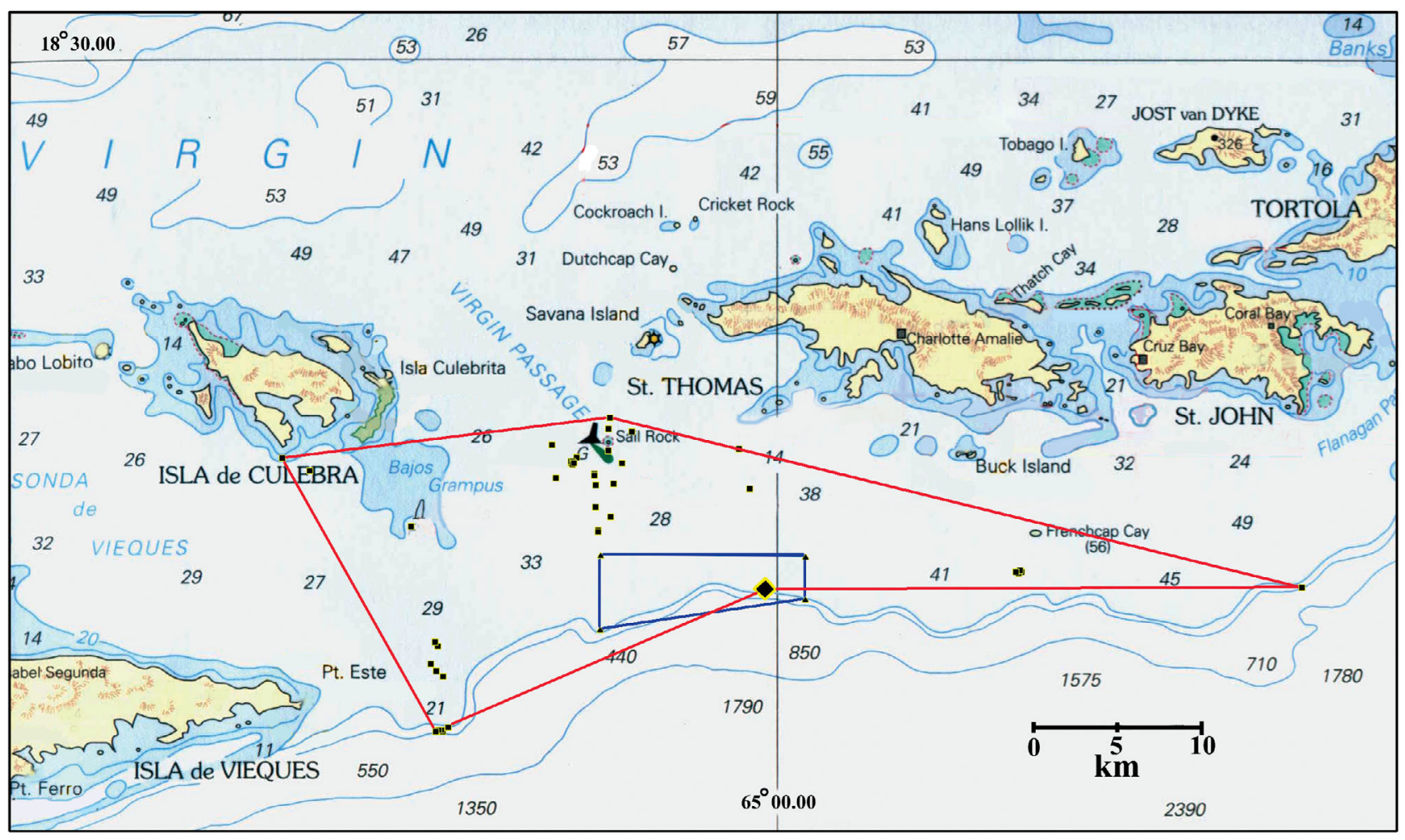

Fig. 1. Chart of northern Virgin Islands and eastern Puerto Rico showing boundaries of the Red Hind Marine Conservation District (small blue trapezoid), minimum boundary of red hind spawning population migration (large red polygon $=500 \mathrm{~km}^{2}$ ), recapture locations of tagged red hind (匹), and location of red hind spawning aggregation $(\bullet)$. Depths in meters 
areas within the MCD including the spawning aggregation site are composed of well developed and diverse coral reefs dominated by Montastraea franksi corals which form 1 to $2 \mathrm{~m}$-wide mushroom-shaped colonies.

Red hind Epinephelus guttatus are long-lived reef fish (11 to $22 \mathrm{yr}$, Luckhurst et al. 1992, Sadovy et al. 1992, Potts \& Manooch 1995) that form annual spawning aggregations. They migrate to spawning sites several weeks before the onset of the spawning season and begin to aggregate 5 to $7 \mathrm{~d}$ before the full moon between December and February. The aggregation usually peaks in January and spawning can occur from 0 to $4 \mathrm{~d}$ before the full moon (Shapiro et al. 1993, Beets \& Friedlander 1999). In January 2000, 2001 and 2003, the area of the red hind spawning aggregation was estimated by drift-fishing, setting fish traps and diving around the aggregation area and recording GPS coordinates when visual counts and catch rates declined rapidly. The GPS coordinates were downloaded into OziExplorer shareware and the resulting polygon marked the outer boundaries of the aggregation. The primary aggregation site was marked with several semi-permanent moorings to assist in relocation and to avoid anchor damage on the coral reef.

Population characterization and assessment. SCUBA diver assessments of Epinephelus guttatus size structure and spawning aggregation density were conducted from December to February during 5 consecutive spawning seasons: 1999-2000, 2000-2001, 2001-2002, 2002-2003, 2003-2004. Since January was the primary spawning month, each spawning season will be referred to by a single calendar year (e.g. the period December 2002 to February 2003 as the 2003 spawning season). Due to rough sea conditions in 2002 and 2004, tag-and-release fishing and gender determination were only conducted during the 2000, 2001 and 2003 spawning seasons (i.e. only diver surveys were conducted in 2002 and 2004). Statistical tests analyzed density, length and biomass of the annual red hind spawning aggregation to determine if significant changes occurred among years following permanent closure of the St. Thomas red hind spawning site and between seasonal closure and permanent closure periods.

Changes in population density among years were assessed using visual SCUBA surveys (no. $100 \mathrm{~m}^{-2}$ ) and trap catches (catch per unit effort, i.e. per trap haul, CPUE). SCUBA surveys consisted of a diver swimming at a constant speed with the tape unreeling behind and recording red hind in the following size classes: $<10 \mathrm{~cm}, 11-20,21-30,31-40$ and $>41 \mathrm{~cm}$. Each diver held a $1 \mathrm{~m}$ wide $\mathrm{T}$-shaped bar constructed of $1.27 \mathrm{~cm}$ PVC pipe and marked with $5 \mathrm{~cm}$ increments that was used to estimate transect width and fish size.
Due to the depth of the spawning aggregation site, each diver was able to complete 3 to 4 belt transects of $30 \times 2 \mathrm{~m}$ each per dive, and a minimum of 6 transects were conducted each day. Most visual surveys were conducted around the full moon period and encompassed the spawning peaks which could occur up to 4 d before the full moon (Beets \& Friedlander 1999, R. S. Nemeth pers. obs.). Visual surveys were used to measure both the average and peak spawning densities. Average spawning density data included counts of red hind throughout the aggregation area $4 \mathrm{~d}$ before and up to $2 \mathrm{~d}$ after the full moon in December, January and February. Peak spawning density data included the maximum density seen on any one day during the spawning period at the approximate center of the primary spawning aggregation site. Beets \& Friedlander (1999) also estimated red hind density by counting fish along 4 transects of $50 \times 8 \mathrm{~m}$ each conducted at the center of the primary spawning aggregation on January 22, 1997, 1 d before the full moon. Based on my knowledge of this spawning aggregation and the fact that this day corresponded to the highest trap-catch rates in their study, the 1997 data most probably represented high average or maximum red hind densities. Since these data approximated maximum density, they were compared to annual peak spawning densities recorded each spawning season. However, as a conservative approach, the 1997 density data were also compared to average densities of red hind when testing for the effect of the MCD closure on spawning aggregation density. To standardize density estimates between years and allow comparison with published literature, only visual counts conducted during the month of January were included in the analysis. Biomass was calculated from fish transect data using the Bohnsack \& Harper (1988) length-weight relationship: $W=a L^{b}$ where $W=$ weight $(g), a=0.0111, b=3.1124$, and $L=$ length $(\mathrm{cm})$. Then $B=W D / 1000$ where $B=$ biomass $\left(\mathrm{kg} 100 \mathrm{~m}^{-2}\right.$ ) and $D=$ fish density (no. $100 \mathrm{~m}^{-2}$ ). Data for maximum spawning density met the assumptions of normality (Kolmogorov-Smirnov test, p > 0.05) and homogeneity of variances (Levene median test, $\mathrm{p}=$ 0.834 ) and were tested with 1-way ANOVA; Tukey's test was used for multiple comparisons. Average density and biomass data did not conform to parametric testing, so the nonparametric Kruskall-Wallis analysis of variance on ranks and Dunn's multiple-comparison tests were used.

Catch-and-release fishing was conducted during 3 of the 5 spawning seasons (Table 1) during the week preceding the full moon and a few days after. Extremely poor weather and rough sea conditions prevented fishing during the 2002 and 2004 seasons. Fishing gear included hand lines with 2 or 3 hooks baited with squid and single-funnel Antillean fish traps with $5.1 \mathrm{~cm}$ 
Table 1. Epinephelus guttatus. Summary catch information for 1999-2000, 2000-2001, 2001-2002, 2002-2003 and 2003-2004 spawning seasons. Date: date of full moon; No. fish trans: no. of fish transects; CPUE: catch per unit effort; -: no trap fishing

\begin{tabular}{|c|c|c|c|c|c|c|c|c|}
\hline Month & Date & $\begin{array}{c}\text { No. fish } \\
\text { trans }\end{array}$ & $\begin{array}{l}\text { No. days } \\
\text { fished }\end{array}$ & $\begin{array}{c}\text { Total } \\
\text { catch (n) }\end{array}$ & $\begin{array}{l}\text { Hand line } \\
\text { catch }(\%)\end{array}$ & $\begin{array}{c}\text { Trap catch } \\
\text { (no. trap sets) }\end{array}$ & $\begin{array}{l}\text { Trap } \\
\text { CPUE }\end{array}$ & $\begin{array}{l}\text { No. } \\
\text { tagged }\end{array}$ \\
\hline Dec $1999^{a}$ & 22 & 5 & 2 & 156 & $146(93.6)$ & $10(7)$ & 1.43 & 124 \\
\hline Jan $2000^{\mathrm{a}}$ & 20 & 15 & 5 & 623 & $469(75.3)$ & $154(54)$ & 2.65 & 511 \\
\hline Feb 2000 & 19 & 2 & 4 & 13 & $7(53.8)$ & $6(18)$ & 0.33 & 5 \\
\hline Year 1 total & & 22 & 11 & 792 & $622(78.5)$ & $170(79)$ & $2.14^{\mathrm{b}}$ & 640 \\
\hline Dec 2000 & 13 & 23 & 4 & 87 & $22(25.3)$ & $65(48)$ & 1.35 & 36 \\
\hline Jan $2001^{a}$ & 9 & 75 & 14 & 936 & $609(65.1)$ & $327(62)$ & 5.27 & 788 \\
\hline Feb $2001^{a}$ & 8 & 30 & 9 & 380 & $228(60.0)$ & $152(54)$ & 2.81 & 322 \\
\hline Year 2 total & & 128 & 27 & 1403 & $859(61.2)$ & $544(164)$ & $4.04^{\mathrm{b}}$ & 1146 \\
\hline Dec $2001^{a}$ & 29 & 24 & 0 & 0 & $0(0)$ & - & - & 0 \\
\hline Jan $2002^{a}$ & 28 & 41 & 2 & 5 & $5(100)$ & - & - & 5 \\
\hline Feb 2002 & 26 & 7 & 0 & 0 & $0(0)$ & - & - & 0 \\
\hline Year 3 total & & 72 & 2 & 5 & $5(100)$ & - & - & 5 \\
\hline Dec 2002 & 19 & 28 & 3 & 73 & $48(65.8)$ & $25(25)$ & 1.00 & 57 \\
\hline Jan $2003^{a}$ & 18 & 42 & 6 & 1114 & $92(8.3)$ & $1022(109)$ & 9.38 & 986 \\
\hline Feb $2003^{a}$ & 16 & 29 & 4 & 211 & $20(9.5)$ & 191 (49) & 3.90 & 162 \\
\hline Year 4 total & & 99 & 13 & 1398 & $160(11.5)$ & $1238(183)$ & $6.64^{\mathrm{b}}$ & 1205 \\
\hline Dec 2003 & 8 & 9 & 0 & 0 & $0(0)$ & - & - & 0 \\
\hline Jan $2004^{\text {a }}$ & 7 & 12 & 1 & 9 & $9(100)$ & - & - & 9 \\
\hline Feb $2004^{a}$ & 6 & 12 & 0 & 0 & $0(0)$ & - & - & 0 \\
\hline Year 5 total & & 33 & 1 & 9 & $9(100)$ & - & - & 9 \\
\hline Total & & 354 & 54 & 3607 & $1656(45.9)$ & $1952(426)$ & $4.27^{b}$ & 3004 \\
\hline
\end{tabular}

(2 inch) square coated-wire mesh baited with local baitfish (Jenkinsia sp. and Anchoa sp.). In 20006 traps were fished, with 10 in 2001 and 12 in 2003. Fishing effort for traps typically consisted of traps being set and hauled twice each day, once in the morning following an overnight set (mean soak time $=21.8 \mathrm{~h}, \mathrm{SD}=$ 5.867, range $=17$ to $45 \mathrm{~h}$ ) and again in the afternoon (mean soak time $=3.8 \mathrm{~h}, \mathrm{SD}=1.195$, range $=2$ to $8 \mathrm{~h}$ ). Short daytime trap sets $(n=227)$, which represented $53 \%$ of the trap effort, were fished between 7:30 and 12:30 $\mathrm{h}$ (mean $=10: 30 \mathrm{~h} \pm 0.047 \mathrm{SD})$ and caught nearly twice as many red hind than long overnight trap sets ( $\mathrm{n}=201$ ), which were usually fished between 14:00 and 10:30 h (mean $=14: 00 \pm 0.070),\left(\chi^{2}=21.83, \mathrm{p}<\right.$ 0.001 ; mean red hind per trap haul: short soak $=5.8 \pm$ 6.56 SD, long soak $=3.1 \pm 4.22 \mathrm{SD}$ ). Trap catch data were compared to Beets \& Friedlander's (1999) study conducted in January 1997. They fished 12 traps constructed with $3.8 \mathrm{~cm}^{2}\left(1.5 \mathrm{inch}^{2}\right)$ mesh baited with local baitfish and used hand lines baited with squid. Beets \& Friedlander (1999) pulled all traps only once a day, usually in the morning, followed by hand-line fishing. Since their $24 \mathrm{~h}$ soak time encompassed that of the 2 trap sets, data from my study were standardized as CPUE and long and short soak data were averaged for statistical comparison. Trap catch data did not conform to parametric testing, so nonparametric Kruskall-Wallis and Dunn's multiple-comparison tests were used.
Effort in hand-line fishing varied throughout the day and was difficult to quantify. For example, hand-line catch rates increased with slack tide and decreased as predatory fishes became more abundant. The number of persons fishing was also inversely related to catch rates. As catch rates increased, at least 2 persons stopped fishing in order to process the red hind and to record data (see below). Moreover, using hand lines as a method of catching fish became relatively less important as more traps were fished and catch rates from fish traps increased. For example, between the 2000 and 2003 spawning seasons, hand-line catch rates decreased from 78.5 to $11.5 \%$, relative to trap catches (Table 1). Since hand-line fishing was difficult to standardize, no attempt was made to calculate its CPUE.

Red hind caught with hand lines and traps had over-inflated air bladders, which were vented using a 14 gauge hypodermic needle in $100 \mathrm{l}$ tubs of seawater. Once fish regained buoyancy they were measured to the nearest $1 \mathrm{~mm}$ total length, tagged with numerically coded Floy T-bar anchor tags (Model FD-68B), and released overboard. Tags were inserted with a tagging gun into the dorsal musculature and through the pterigiophores of the second dorsal fin. Prior to release the abdomen of each fish was squeezed lightly, and if eggs or milt emerged, the gender was noted. In Year 4, gender was determined using ultrasound imaging (Whiteman et al. 2005). 
Efforts were made to decrease mortality associated with catch-and-release fishing by reducing the amount of time that fish spent aboard the fishing vessel and increasing the supply of fresh seawater. Moreover, during the 2003 spawning season a specialized release cage was constructed that allowed fish to be lowered to the seafloor and remotely released, thus minimizing predation in the water column. These efforts were partly successful in that mortality associated with capture declined from $18 \%$ ( $n=141$ fish) in the first year, to $14.4 \%$ ( $\mathrm{n}=193 \mathrm{fish}$ ) in the second year to $11.5 \%$ ( $\mathrm{n}=156$ fish) in the last year of fishing (i.e. 2003 spawning season). Mortality, when it occurred, resulted from excessive bleeding from hook injury, air embolism from gas bladder expansion during ascent to the surface, or predation during retrieval or release of fish. The primary predators that attacked red hind near the boat were barracuda Sphyraena barracuda and occasionally king mackerel Scomberomorous cavalla and lemon sharks Negaprion brevirostris. Potential predators near the reef, in addition to those mentioned above, included large snappers Lutjanus cyanopterus and L. joco, green moray eels Gymnothorax funebris, nurse sharks Ginglymostoma cirratum and reef sharks Carcharhinus perezii. Green morays also contributed to pre-tagging mortality when they entered fish traps at night and swallowed several adult red hind.

Fish that did not survive capture were returned to the laboratory, measured, weighed to the nearest $0.1 \mathrm{~g}$, and sexed by visual and microscopic inspection of their reproductive structures (Shapiro et al. 1993). A subsample of these fish was measured for total length (TL) and standard length (SL) which established the following relationship: $\mathrm{TL}=1.6415+1.1174 \mathrm{SL}\left(\mathrm{r}^{2}=\right.$ $0.98, \mathrm{n}=23$ ). Data on fish weight conformed to assumptions of ANOVA (Kolmogorov-Smirnov test for normality $\mathrm{p}>0.05$ and Levene test for homogeneity of variances $\mathrm{p}=0.433)$. Analysis of covariance was used to test for differences in weight of males and females between years after homogeneity of regression slopes were confirmed (males: $F_{(1,81)}=0.48, \mathrm{p}=0.49$, female: $\left.F_{(1,27)}=0.13, \mathrm{p}=0.72\right)$. Weights for red hind are reported as adjusted least-square means.

Movement patterns and habitat usage. During the primary spawning week in January of 2000, 2001 and 2003, exploratory fishing with hand lines and traps was used to determine the boundary, and calculate the area of the spawning aggregation. Within this boundary occasional fish transects were conducted to verify the presence of red hind and calculate densities. Average densities of red hind throughout the aggregation area were used to estimate total number of fish within the spawning population.

Between January 4 and February 15, 2001, additional fish transects were conducted to record changes in red hind density and evaluate coral habitat usage patterns between monthly spawning peaks. Catch-and-release fishing was also continued every couple of days during this same period to determine the size structure of the spawning population between spawning peaks.

The tag-and-release program was designed to gather information on the source area of spawning population, migratory distance, time spent on the MCD spawning site and growth rates. The writing on each Floy tag included: a unique fish identification code, a local telephone number and a '\$20 reward'. Press releases, fishermen workshops, and the distribution of reward posters at fishing ports and fish markets in St. Thomas, St. John, St. Croix, Culebra, Vieques, eastern Puerto Rico and the British Virgin Islands informed commercial and recreational fishermen of the tag reward program. Fishermen who returned a tag could receive the reward in exchange for information on date and location of capture. Fishermen who returned tagged red hind were paid market value for the fish in order to measure growth rates.

To document migratory pathways, Sonotronics acoustic tags (Model CT-82-2) were surgically implanted in the body cavity of 2 fish in January 2000 and 8 fish in January 2001. Prior to incision the area was sterilized with iodine then sutured following insertion of tag. Once the fish had recovered in a tub of flowing seawater it was carried in a mesh bag to the reef by divers, released by hand, and monitored for 10 to 15 min. Such fish were followed daily using a Sonotronics narrow-band tracking receiver (Model USR-96) and directional hydrophone (Model DH-4) until their signals were lost.

Statistical analysis of historical data. Results on population characteristics of the St. Thomas red hind spawning aggregation from this study were compared to data collected in 1997 during the seasonal closure period by Beets \& Friedlander (1999). Statistical tests were conducted on fish length and weight, density, and biomass of the annual red hind spawning aggregation to determine if significant changes occurred following permanent closure of the St. Thomas Marine Conservation District, which included the red hind spawning aggregation site. This study was started in December 1999 (i.e. the Year 2000 spawning season), the same month that the MCD was established. Thus, the Year 2000 spawning season was considered part of the seasonal closure period because the characteristics of the red hind spawning population during this time period would still represent the effect of the seasonal closure and not that of the $\mathrm{MCD}$. Any changes to the red hind spawning population that could be attributed to the MCD would not be evident until the following spawning season (i.e. December 2000 to February 2001), since the effective start date of the MCD was really March 1, 2000, the date the seasonal 
closure would have ended. Thus, data from the 1997 and 2000 spawning seasons were considered part of the seasonal closure period, whereas the spawning seasons 2001, 2002, 2003 and 2004 were considered part of the permanent closure period. Density and biomass data were available for all years, whereas fish length, weight and catch data were available for only 1997 (Beets \& Friedlander 1999) and 2000, 2001 and 2003 (this study). The null hypothesis that no difference in fish length, weight, density, biomass and CPUE of red hind existed before and after the establishment of MCD was tested using a 1-way ANOVA when data conformed to assumptions of parametric testing or a Kruskall-Wallis ranks test when data did not (see second subsection of 'Materials and methods').

To examine the impact of the MCD closure on the length of red hind caught in the fishery, size-frequency data from the beginning of the seasonal closure (1990) were extracted from published literature and reports, the National Marine Fisheries Service (NMFS) biostatistical database, and the Virgin Islands Division of Fish and Wildlife sea map and port surveys (VIDFW). This included 1992 to 1996 and 2002 (NMFS), and 1999, 2000, 2002 and 2003 (VIDFW). When appropriate, these historical fish length data, often reported as $\mathrm{SL}$, were converted to $\mathrm{TL}$ using the equation $\mathrm{TL}=$ $1.6415+1.1174 \mathrm{SL}$ (see second subsection of 'Materials and methods'). Statistical tests on these data considered 1991 through 1999 as seasonal closure and 2000 through 2003 as permanent closure. In this case, Year 2000 is included as part of the permanent closure period since port surveys in this year were conducted after the establishment of the MCD (i.e. after February 2000). The null hypothesis was tested using a nonparametric Kruskall-Wallis ranks test, which revealed no difference in fish length before and after establishment of the MCD.

\section{RESULTS}

\section{Spawning population abundance}

The average density of red hind, estimated from fish transects $(n=354)$, varied among months and years. Red hind aggregated to spawn in December and January of the first (1999 to 2000) and third (2001 to 2002) years of the study, in January and February of the second (2000 to 2001) and fifth (2003 to 2004) years of the study, and primarily in January of the fourth year of the study (2002 to 2003) (Fig. 2). The spawning peak typically occurred within $2 \mathrm{~d}$ of the January full moon of each year. Only in February 2001 did the density of red hind exceed the January spawning density (Fig. 2), but this difference was not significant: $F_{(1,68)}=0.85, \mathrm{p}=$

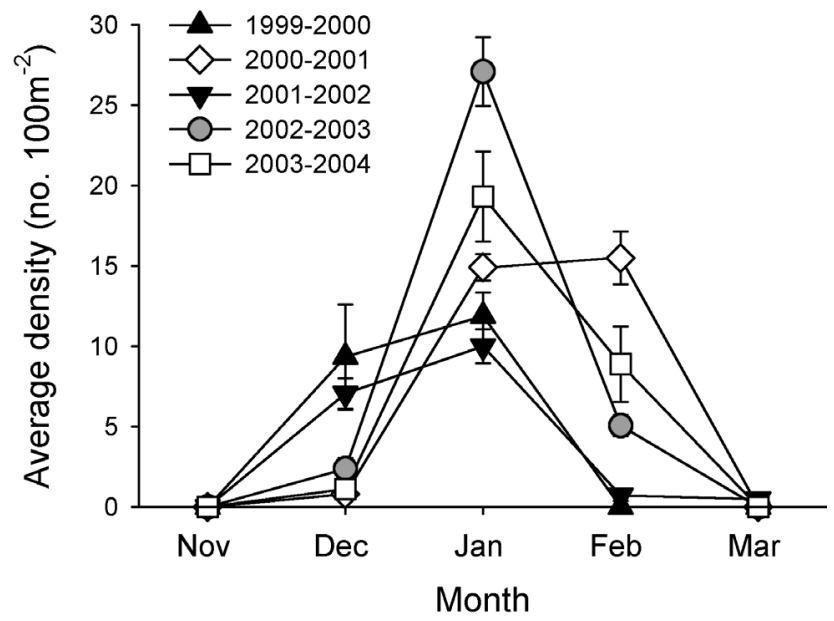

Fig. 2. Epinephelus guttatus Average $( \pm \mathrm{SE})$ density in primary spawning aggregation site in St. Thomas, US Virgin Islands (USVI), from November to March. Symbols indicate primary months of spawning in the relevant years

0.36. Beets \& Friedlander (1999) recorded 4.7 red hind $100 \mathrm{~m}^{-2}( \pm 1.0 \mathrm{SD})$ on January 22, $19971 \mathrm{~d}$ before full moon. On this same day, trap catch rates peaked (Beets \& Friedlander 1999), suggesting that the 1997 density estimate most probably represented the maximum density of spawning red hind, or at least a high average density. Since this value was a good approximation of maximum density, these data were compared with annual peak spawning densities found in this study. However, as a conservative approach, the 1997 density data were also used to compare average densities of red hind before and after MCD closure. Maximum spawning density of red hind was significantly greater in 2003 than in all other years (Fig. 3, $F_{(4,34)}=$

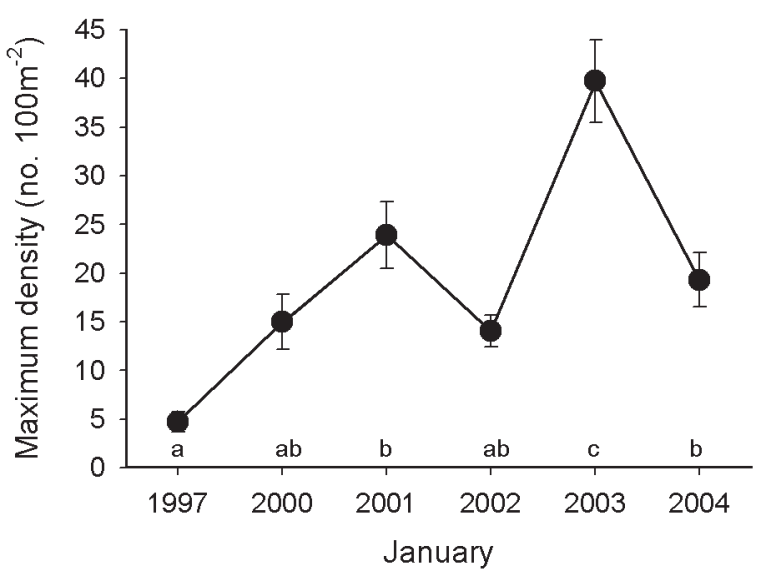

Fig. 3. Epinephelus guttatus. Maximum $( \pm \mathrm{SE})$ spawning density (no. fish $100 \mathrm{~m}^{-2}$ ) recorded during the January spawning peak for 6 spawning seasons at St. Thomas, USVI, red hind bank: 1997 ( $\mathrm{n}=4$ transects), $2000(\mathrm{n}=6), 2001(\mathrm{n}=6), 2002$ $(n=9), 2003(n=6)$, and $2004(n=12)$. Letters above $x$-axis indicate significant differences from Tukey's multiplecomparison test at $\mathrm{p}<0.05$ 
10.253, $\mathrm{n}=43, \mathrm{p}<0.001$ ). The maximum density of red hind more than doubled after the MCD took effect (before $\mathrm{MCD}=10.39$ red hind $100 \mathrm{~m}^{-2} \pm 3.92 \mathrm{SD}$ vs. after $\mathrm{MCD}=24.25$ red hind $100 \mathrm{~m}^{-2} \pm 8.32 \mathrm{SD}$ ). The average density of red hind changed significantly between the seasonal closure period (data from 1997 and 2000 spawning seasons) and after the MCD was established (Fig. 4A, average density before $\mathrm{MCD}=10.4$ red hind $100 \mathrm{~m}^{-2} \pm 5.81 \mathrm{SD}$, after $\mathrm{MCD}=16.7$ red hind $100 \mathrm{~m}^{-2} \pm 11.49$; Mann-Whitney $U$-test $=113.5, \mathrm{n}=43$, $\mathrm{p}<0.002)$.

A total of 3607 red hind were captured and measured during $3 \mathrm{yr}$ of sampling with hand lines and fish traps (Table 1). Trap catches for the entire study period averaged 3.0 red hind $\operatorname{trap}^{-1}( \pm 4.27 \mathrm{SD}, \mathrm{n}=426$ trap sets) and ranged from 0 to 31 red hind trap ${ }^{-1}$. CPUE for the 2 primary spawning months of each year (see Table 1) increased significantly between 2000 and 2003 (Kruskal-Wallis $H=44.38, \mathrm{n}=355, \mathrm{p}<0.001$ ). The MCD had a significant effect on January trap catches (Fig. 4B, Mann-Whitney $U$-test $=6092, \mathrm{n}=294, \mathrm{p}<0.001$ ).

The mean biomass of spawning red hind increased by over $60 \%$ between the seasonal closure period (1997 and 2000) and after the establishment of the
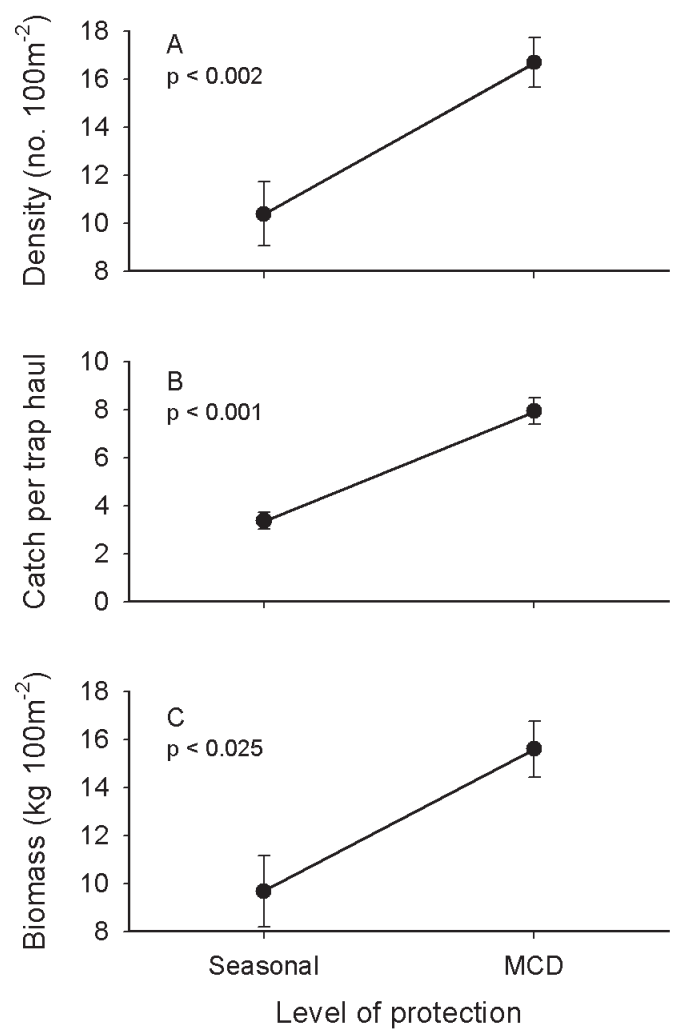

Fig. 4. Epinephelus guttatus. Mean $( \pm \mathrm{SE})$ change in $(\mathrm{A})$ average density, (B) catch per trap haul and (C) biomass during seasonal closure and after the Red Hind Bank Marine Conservation District (MCD) was established at St. Thomas, USVI. $\mathrm{p}<0.05$ indicates significant change between level of protection
MCD (2001 and 2003) (Fig. 4C, Mann-Whitney $U$-test = 1222, $\mathrm{n}=116, \mathrm{p}<0.025)$. Biomass estimates from SCUBA surveys for January of each year were 2000: $11.2 \mathrm{~kg} 100 \mathrm{~m}^{-2}( \pm 6.48 \mathrm{SD}) ; 2001: 9.2 \mathrm{~kg} 100 \mathrm{~m}^{-2}$ $\left( \pm 5.64\right.$ SD); 2002: $10.1 \mathrm{~kg} 100 \mathrm{~m}^{-2}( \pm 4.10 \mathrm{SD})$; 2003: $25 \mathrm{~kg} 100 \mathrm{~m}^{-2}$ ( $\left.\pm 13.10 \mathrm{SD}\right) ; 2004: 18.7 \mathrm{~kg} 100 \mathrm{~m}^{-2}$ $( \pm 10.30 \mathrm{SD})$. Biomass of red hind in 1997 was estimated from Beets \& Friedlander (1999) to be $3.8 \mathrm{~kg} 100 \mathrm{~m}^{-2}$. The maximum rate of change in biomass from 1997 to 2003 represented a $550 \%$ increase in a 6 yr period.

The area of the red hind aggregation within the MCD was calculated to be $0.24 \mathrm{~km}^{2}$ in both 2000 and 2001 and $0.35 \mathrm{~km}^{2}$ in 2003. This increase resulted from red hind occupying a larger area of contiguous coral reef to the west of the primary spawning aggregation. The average density of spawning red hind throughout the entire aggregation area (averaged from transects done from $4 \mathrm{~d}$ before to $1 \mathrm{~d}$ after full moon) for January 2000, 2001 and 2003 were 11.2, 16.4 and 24.0 red hind $100 \mathrm{~m}^{-2}$, respectively. By multiplying the area of the aggregation by the average density of spawning red hind throughout this area, the total number of fish within the red hind spawning population was estimated to be 26229 in 2000, 38143 in 2001 and 84000 in 2003. The dramatic increase of the spawning population between January 2000 and 2003 resulted from a combination of the westward expansion of the spawning aggregation and the higher densities of red hind within this area. The continuity of the spawning aggregation from the primary site to the western boundary was verified using fishing and diver surveys and was supported by concurrent increases in trap CPUE and biomass during this same time period (Table 1 , Fig. 4B,C).

\section{Spawning population size structure}

The length of red hind in the spawning aggregation increased significantly toward the end of the seasonal closure (Fig. 5, Kruskal-Wallis $H=72.89, \mathrm{n}=3902, \mathrm{p}<$ $0.001)$. Following the MCD closure, the size of fish in the spawning aggregation reached a plateau and even declined slightly from $38.8 \mathrm{~cm}$ in 2000 to $37.9 \mathrm{~cm}$ in 2003 (Fig. 5). This resulted in no significant change in fish length between the seasonal closure and MCD periods (Kruskal-Wallis $H=0.14, \mathrm{n}=3902, \mathrm{p}>0.05$ ). However, analysis of port sampling data indicated that the length of red hind caught by the commercial fishery increased significantly after the MCD was established (Fig. 5; total length before MCD $=32.4 \mathrm{~cm}$ $\pm 6.06 \mathrm{SD}$, after $\mathrm{MCD}=34.4 \mathrm{~cm} \pm 5.10 \mathrm{SD}$, MannWhitney $U$-test $=60149, \mathrm{n}=637, \mathrm{p}<0.001$ ).

Within each spawning season, the average size of fish differed significantly between months. Red hind 


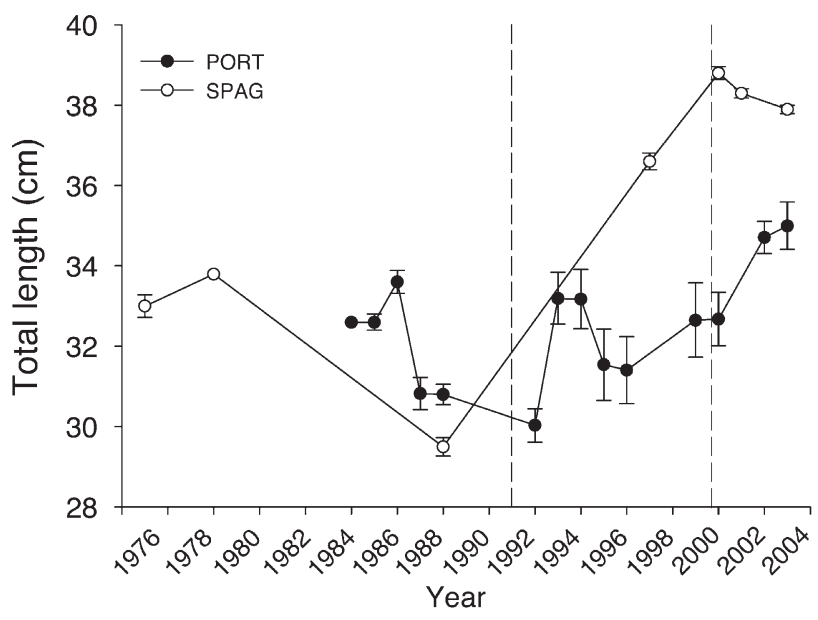

Fig. 5. Epinephelus guttatus. Mean $( \pm \mathrm{SE})$ total length $(\mathrm{cm})$ of St. Thomas red hind population over past $30 \mathrm{yr}$ collected from port surveys (PORT) and red hind spawning aggregations (SPAG). Dashed vertical lines indicate start of seasonal closure in November 1990 and establishment of MCD in December 1999. Data recalculated from Olsen \& LaPlace (1978), Sylvester et al. (1978), Morales-Santana (1984), Clavijo \& Tobias (1985), Bohnsack et al. (1986), Clavijo et al. (1986), Beets \& Friedlander (1992), Sadovy \& Figuerola (1992), Sadovy et al. (1992), Cummings et al. (1997), Beets \& Friedlander (1999), and National Marine Fisheries Service biostatistical data, Virgin Islands Division of Fish and Wildlife. Measurements in standard lengths (SL) were converted to total lengths (TL) using equation $\mathrm{TL}=1.6415+1.1174 \mathrm{SL}\left(\mathrm{r}^{2}=0.98, \mathrm{n}=23\right.$ : see second subsection of 'Materials and methods').

were consistently larger in December of each spawning season whether or not it was a primary spawning month (Fig. 6, Kruskal-Wallis, 1999 to 2000: $H=55.07$, $\mathrm{n}=783, \mathrm{p}<0.001 ; 2000$ to 2001: $H=13.70, \mathrm{n}=1321, \mathrm{p}$ $<0.001$; and 2002 to 2003: $H=90.60, \mathrm{n}=1383$, p < 0.001). Between the years 2000, 2001 and 2003, the

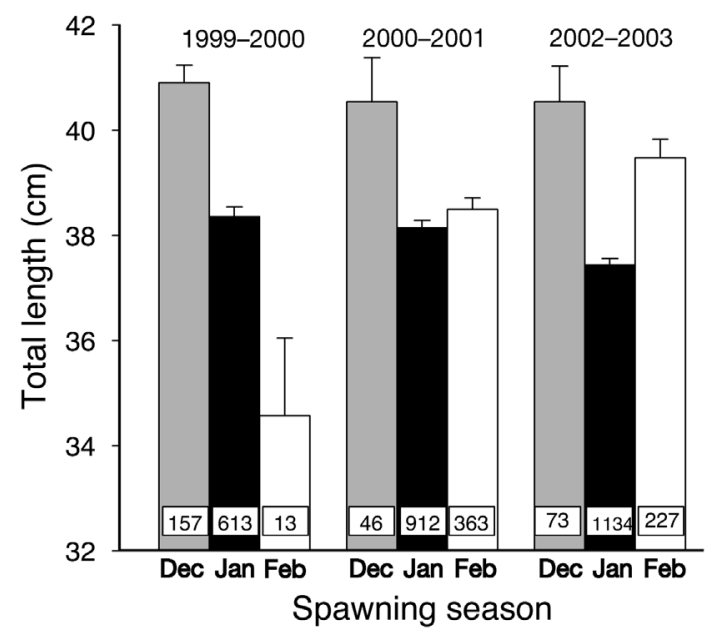

Fig. 6. Epinephelus guttatus. Mean $( \pm \mathrm{SE})$ total length $(\mathrm{cm})$ of aggregating fish during each 3 mo spawning season in St. Thomas, USVI. Sample sizes are shown at base of bars; primary spawning months indicated in bold size of fish remained largely unchanged during successive Decembers ( $p=0.898)$, decreased each January (Kruskal-Wallis $H=19.48, \mathrm{n}=2658, \mathrm{p}<0.001$ ) and increased each February (Kruskal-Wallis $H=17.35$, $\mathrm{n}=604, \mathrm{p}<0.001)$. The data for February 2000 should be interpreted with caution since this was not a primary spawning month and the sample size was small (Fig. 6). Since January was the primary spawning month each season it had the largest sample size of any month and had a strong influence on the overall fish size among years. The decrease in fish length from 2000 to 2003 during this month (Fig. 6) most probably contributed to the overall decline in average fish length between years (Fig. 5).

The total length of fish collected by hand line was $0.8 \mathrm{~cm}$ larger than fish caught in traps in 2001 (hand line $=38.6 \mathrm{~cm} \pm 4.32 \mathrm{SD}$, trap $=37.8 \mathrm{~cm} \pm 3.92 \mathrm{SD}$, Kruskal-Wallis $H=8.72, \mathrm{n}=1310, \mathrm{p}<0.003)$ and 2003 (hand line $=38.6 \mathrm{~cm} \pm 4.81 \mathrm{SD}$, trap $=37.9 \mathrm{~cm} \pm$ 3.72 SD, Kruskal-Wallis $H=4.69, \mathrm{n}=1224, \mathrm{p}<0.03)$. The proportion of red hind caught with hand line declined from $78.5 \%$ in 2000 to $11.5 \%$ in 2003 (Table 1). This slight gear bias may have also contributed to the $0.9 \mathrm{~cm}$ decline in average fish length during this period (Fig. 5).

The dominant size class of red hind calculated from SCUBA transects was 31 to $40 \mathrm{~cm}$ during all $5 \mathrm{yr}$ (Fig. 7). There was an annual trend of increasing dominance of the larger size classes (i.e. 31 to 40 and $>41 \mathrm{~cm}$ ) and a subsequent decrease of smaller size classes from 2000 to 2004 . Red hind $<10 \mathrm{~cm}$ in length were also observed by divers and were found in the regurgitated gut contents of 2 adult red hind, indicating that recruitment of juvenile red hind may actually be occurring on these deeper reefs.

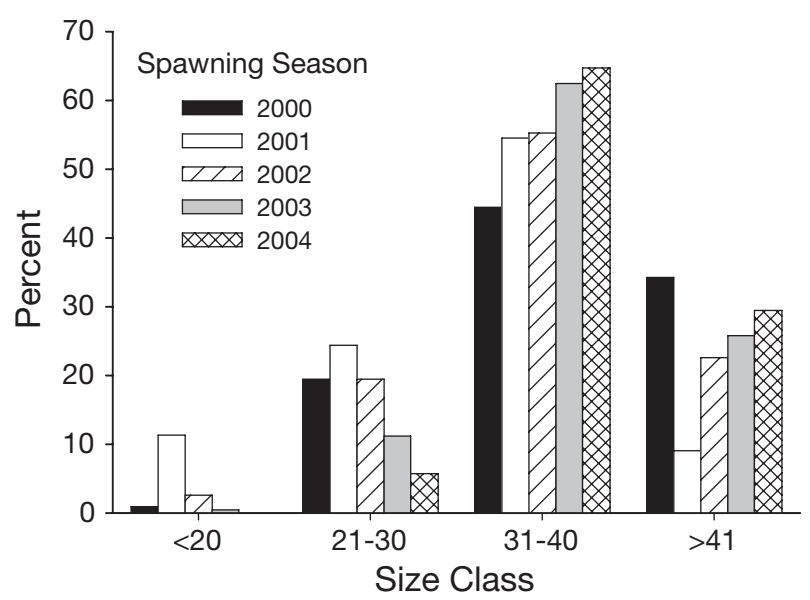

Fig. 7. Epinephelus guttatus. Percent size distribution of fish estimated from diver transects conducted at the red hind bank, St. Thomas, USVI, during January spawning aggregations of each year ( $\mathrm{n}=$ no. transects): $2000(\mathrm{n}=15), 2001$ $(n=21), 2002(n=28), 2003(n=36), 2004(n=12)$ 
Table 2. Epinephelus guttatus. Mean \pm SD. Total length and weight of male and female red hind from St. Thomas spawning aggregation. Individual letters in multiple comparisons indicate significant differences among years $(\mathrm{p}<0.05) .1997$ data from Beets \& Friedlander (1999). $\mathrm{n}=$ number of fish

\begin{tabular}{|lcccccc|}
\hline Year & $\mathrm{n}$ & Length $(\mathrm{cm})$ & $\mathrm{p}$ & $\mathrm{n}$ & Weight $(\mathrm{g})$ & $\mathrm{p}$ \\
\hline Male & & & & & & \\
1997 & 91 & $40.7 \pm 2.66$ & $\mathrm{~A}$ & 91 & $1008 \pm 221.7$ & $\mathrm{~A}$ \\
2000 & 106 & $41.8 \pm 3.90$ & $\mathrm{~B}$ & 76 & $1168 \pm 309.3$ & $\mathrm{AB}$ \\
2001 & 39 & $41.4 \pm 1.71$ & $\mathrm{AB}$ & 9 & $1174 \pm 182.4$ & $\mathrm{AB}$ \\
2003 & 49 & $42.3 \pm 3.15$ & $\mathrm{~B}$ & 48 & $1199 \pm 286.6$ & $\mathrm{~B}$ \\
Female & & & & & & \\
1997 & 264 & $35.3 \pm 3.36$ & $\mathrm{~A}$ & 264 & $666 \pm 215.8$ & $\mathrm{~A}$ \\
2000 & 51 & $39.4 \pm 3.31$ & $\mathrm{~B}$ & 10 & $865 \pm 248.0$ & $\mathrm{~B}$ \\
2001 & 37 & $34.6 \pm 3.11$ & $\mathrm{~A}$ & 21 & $721 \pm 205.5$ & $\mathrm{AC}$ \\
2003 & 139 & $36.4 \pm 3.42$ & $\mathrm{~A}$ & 118 & $821 \pm 253.6$ & $\mathrm{C}$ \\
\hline
\end{tabular}

The greatest period of change observed in the average length of males and females occurred between 1997 and 2000 (Table 2). Although this time period represented the end of the seasonal closure, the establishment of the MCD also had a positive effect on the total length and weight of females (length before MCD $=35.4 \mathrm{~cm} \pm 3.45 \mathrm{SD}$, after $\mathrm{MCD}=36.2 \mathrm{~cm} \pm 3.43 \mathrm{SD}$, Mann-Whitney $U$-test $=21757, \mathrm{n}=413, \mathrm{p}<0.018$; weight before $\mathrm{MCD}=672 \mathrm{~g} \pm 219.7 \mathrm{SD}$, after $\mathrm{MCD}=$ $806 \mathrm{~g} \pm 248.9 \mathrm{SD}$, Mann-Whitney $U$-test $=24916, \mathrm{n}=$ $413, \mathrm{p}<0.001)$. The maximum length of females increased from $43.9 \mathrm{~cm}$ to $44.5 \mathrm{~cm}$ over the study period (Fig. 8). Although the MCD had no effect on the average length or weight of males, their maximum size range increased dramatically from $48 \mathrm{~cm}$ in 1999-2000 to $54.6 \mathrm{~cm}$ in 2002-2003 (Fig. 8). An increase in the percentage of the youngest size classes of females in the 2002 to 2003 spawning season may be indicative of recruitment of young females into the spawning population. There was also a shift in the dominant size class of females from $36 \mathrm{~cm}$ in 1999-2000, to $36-38 \mathrm{~cm}$ in 2000-2001 to 38-40 in 2002-2003 (Fig. 8). Most interesting, was a decrease in the $42 \mathrm{~cm}$ size class of females in 2000 to 2001 and a subsequent increase in the $42 \mathrm{~cm}$ size class of males in 2002 to 2003 (Fig. 8), suggesting that a cohort of females may have changed sex during the previous 2 years to accommodate the recruitment of young females into the spawning population.

Growth rates, calculated from recaptured red hind, were greatest during the first 1 to 3 mo postspawning $\left(0.18 \mathrm{~mm} \mathrm{~d}^{-1} \pm 0.38 \mathrm{SD}, \mathrm{n}=74\right.$, mean days at liberty $=33.2 \mathrm{~d}$, range $=1$ to $77 \mathrm{~d}$ ). Fish that were recaptured 6 to 36 mo after release had average growth rates of only $0.043 \mathrm{~mm} \mathrm{~d}^{-1} \pm 0.065$ or $15.7 \mathrm{~mm} \mathrm{yr}^{-1}$ $(\mathrm{n}=31$, mean days at liberty $=488 \mathrm{~d}$, range $=138$ to $1138 \mathrm{~d}$ ).
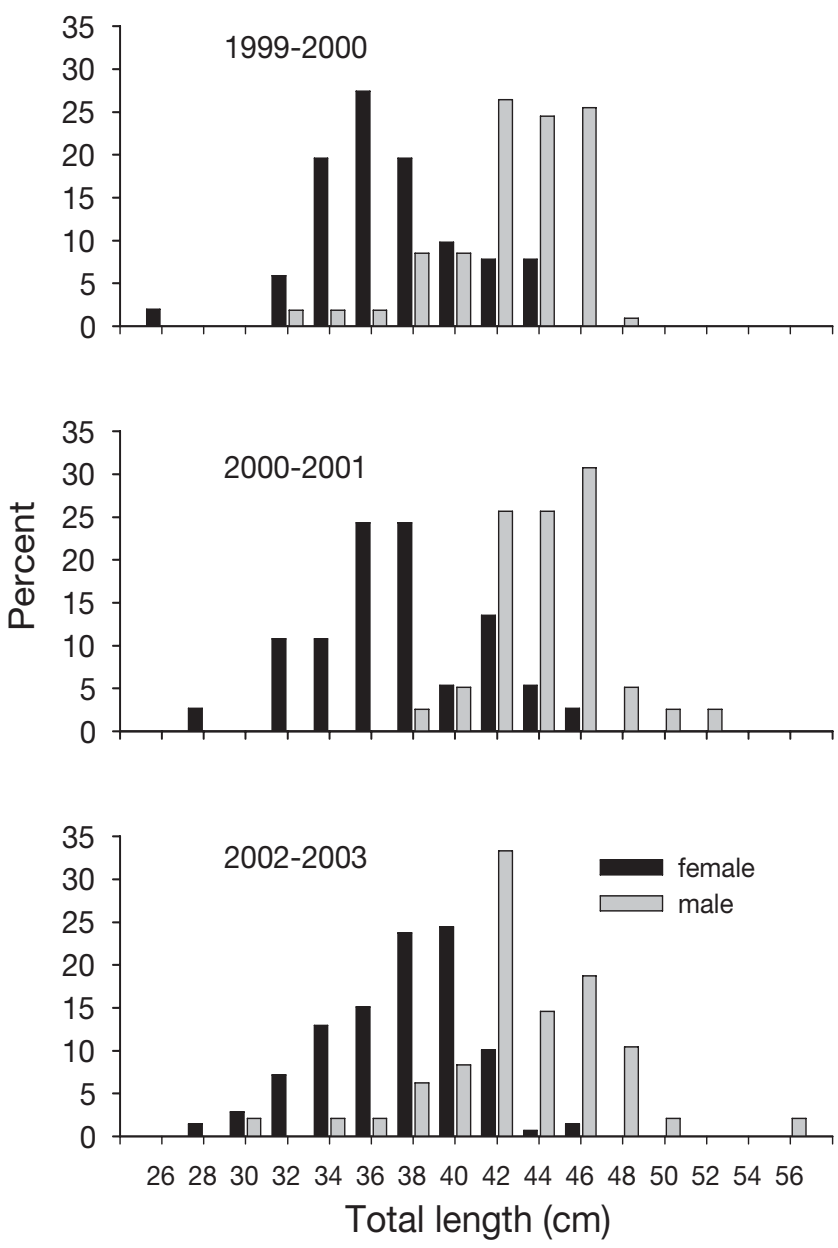

Fig. 8. Epinephelus guttatus. Size-frequency distribution of St. Thomas, USVI, fish spawning aggregation by gender in 1999 and 2000 (mean size: female $36.2 \mathrm{~cm} \pm 3.56, \mathrm{n}=51$; male $41.8 \mathrm{~cm} \pm 3.28, \mathrm{n}=106$ ), 2000 and 2001 (mean size: female $36.4 \mathrm{~cm} \pm 3.82, \mathrm{n}=37$; male $43.5 \mathrm{~cm} \pm 2.44, \mathrm{n}=39$ ) and 2002 and 2003 (mean size: female $36.5 \mathrm{~cm} \pm 3.47, \mathrm{n}=139$; male $42.3 \mathrm{~cm} \pm 4.12, \mathrm{n}=49$ ). $X$-axis labels show upper end of size range (i.e. $26=24.1$ to $26 \mathrm{~cm}$ )

\section{Movement patterns and habitat usage}

Small-scale movement, habitat usage and population characteristics between full moon spawning periods were evaluated with 105 fish transects and $23 \mathrm{~d}$ of catchand-release fishing completed between January 4 and February 10, 2001. The emerging pattern showed that red hind aggregated at high densities during the week preceding the full moon, reached peak densities on the full moon, and that 50 to $80 \%$ of the population then dispersed for about $3 \mathrm{wk}$ before reforming the aggregation (Fig. 9A). In late January 2001 large numbers of red hind were observed 50 to $100 \mathrm{~m}$ (or more) off the primary coral reef in areas composed of sand, rubble and patchreef habitat. A census of this area on January 31, 2001, verified this observation (Fig. 9A). Red hind that re- 

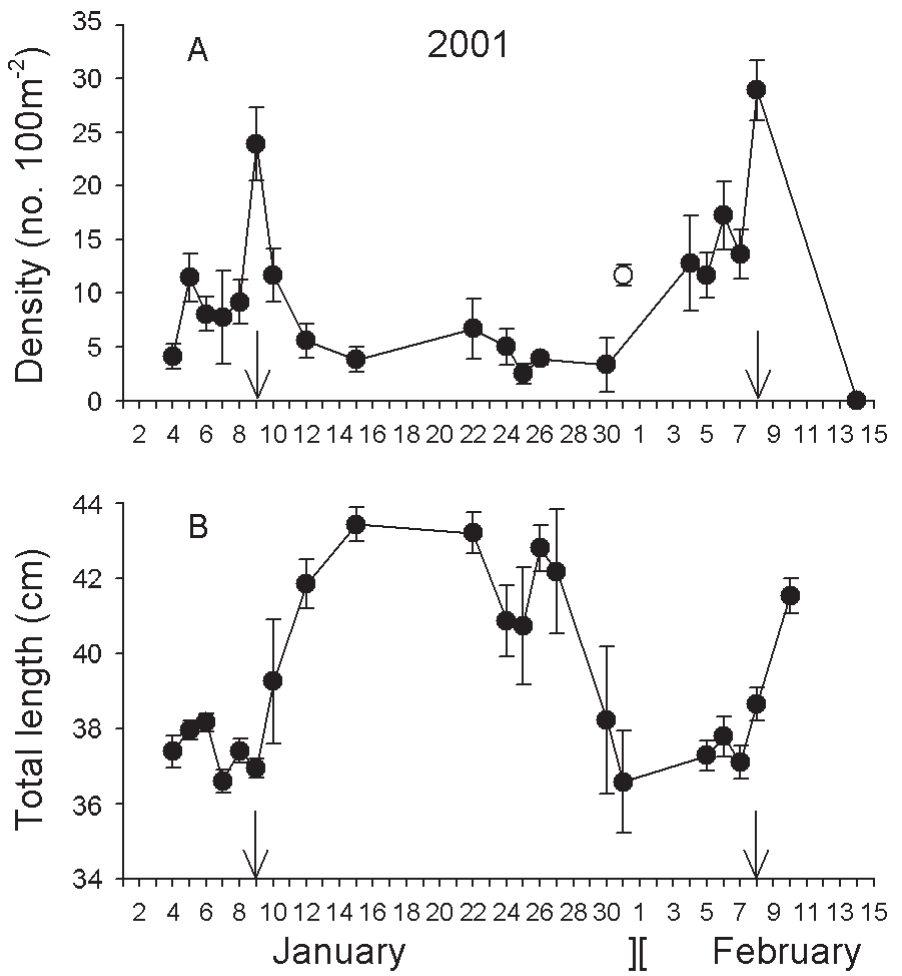

Fig. 9. Epinephelus guttatus. Results of intensive sampling of (A) mean $( \pm \mathrm{SE})$ fish density from transects and (B) mean $( \pm \mathrm{SE})$ total length measured during catch-and-release fishing between spawning peaks in January and February 2001 at St. Thomas USVI red hind bank spawning aggregation site. Arrows show dates of full moon. (O) sampling date that fish transects were made $100 \mathrm{~m}$ off the primary spawning coral habitat in an area of small patch reefs, sand and rubble
During the first 2 spawning seasons, 3004 fish were successfully tagged and released. Of these, 130 fish $(4.3 \%)$ were recaptured either on the spawning grounds during subsequent sampling $(\mathrm{n}=84)$ or were recaptured by fishermen outside the $\mathrm{MCD}(\mathrm{n}=46)$ and returned to the University of the Virgin Islands for reward; 8 tags were returned by commercial fisherman in Vieques, 1 from a commercial fisherman in St. Thomas, and the remaining tags by recreational fisherman. Although many St. Thomas commercial fishermen insisted that no tagged hind had been caught in traps, it leaves one skeptical of the actual participation from this sector of the fishery. Nearly $50 \%$ of red hind recaptured outside the MCD were caught within 4 mo of release (Fig. 10). The majority of red hind caught outside the MCD had migrated an average of $15.6 \mathrm{~km}( \pm 5.17 \mathrm{SD}$, range $=6$ to $33 \mathrm{~km})$ north and westward of the spawning site to their home territory (Fig. 1). Telemetry data confirmed this pattern. Of the 10 red hind that were tracked using acoustic tags, all moved westward following the coral reef ridges before the signal was lost. The maximum distance a fish was tracked was about $3 \mathrm{~km}$. Based on the tag-recapture data, it was calculated that the red hind spawning aggregation south of St. Thomas draws fish from an area of at least $500 \mathrm{~km}^{2}$.

\section{DISCUSSION}

The St. Thomas Red Hind Bank Marine Conservation District was closed seasonally in November 1990 and permanently in December 1999 to protect an important red hind Epinephelus guttatus mained on the spawning aggregation site averaged $42.1 \mathrm{~cm}( \pm 1.02 \mathrm{SD})$. Fish that were collected and measured between January 12 and 27 and on February 10 were significantly larger than the mean population size during spawning (repeated-measures ANOVA $F_{(20,176)}=13.686, \mathrm{p}<0.001$, Fig. 9B). Based on size estimates of males and females (Table 2), these data suggest that females depart the spawning site while males remain until the next spawning period. Red hind had reformed the spawning aggregation on the primary coral reef spawning habitat $1 \mathrm{wk}$ prior to the February full moon. Within 1 wk following the February full moon, the spawning population rapidly and completely departed from the spawning aggregation site (Figs. $2 \& 9$ ).

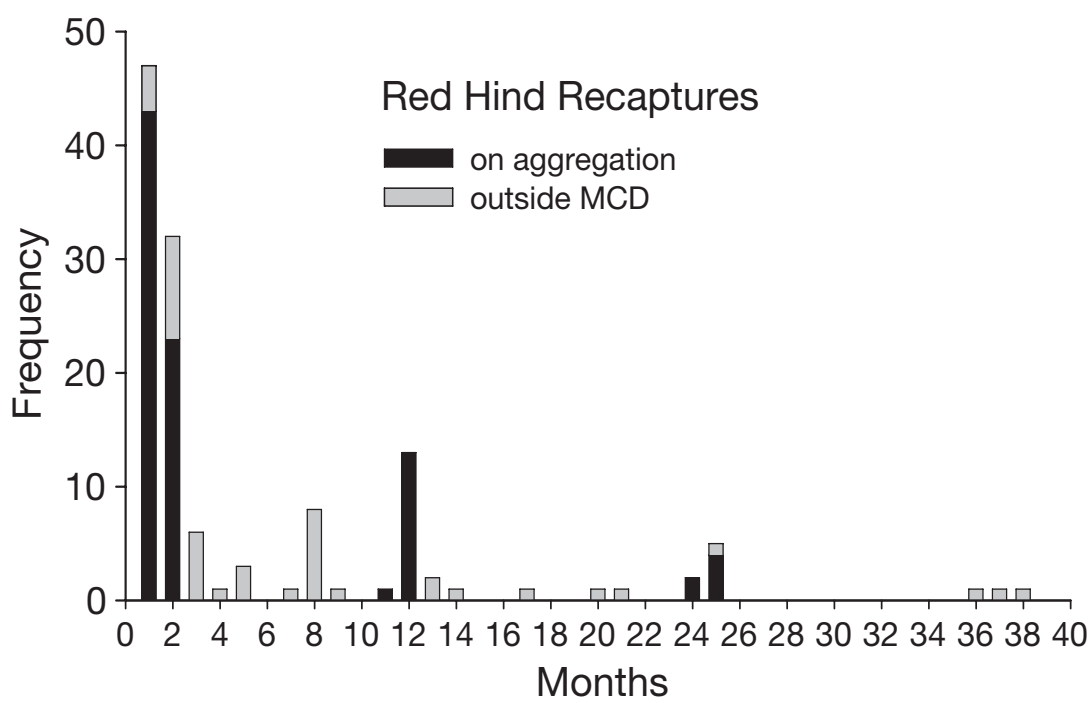

Fig. 10. Epinephelus guttatus. Number of tagged red hind recaptured in spawning aggregation within $(\mathrm{n}=84)$ and outside $(\mathrm{n}=46)$ St. Thomas MCD between December 1999 and March 2004 
spawning aggregation, to improve the declining red hind population and protect critical fisheries habitat. The seasonal closure resulted in impressive improvements in fish length and sex ratios of the spawning aggregation (Beets \& Friedlander 1999). The establishment of the MCD following the seasonal closure provided a unique opportunity to examine the population response of a red hind spawning aggregation to this new management action and evaluate the effectiveness of a relatively large reserve (Halpern 2003) on the red hind fishery.

Since these management measures were implemented, the red hind spawning aggregation has shown positive trends in several population characteristics. Beets \& Friedlander (1999) first collected density data on this red hind spawning aggregation in 1997, $7 \mathrm{yr}$ after seasonal closure. During the last $3 \mathrm{yr}$ of the seasonal closure, from 1997 to 2000, the density of the spawning population increased by over $200 \%$ (4.7 to 15.0 fish $100 \mathrm{~m}^{-2}$ ) or about $66 \% \mathrm{yr}^{-1}$. Following the establishment of the MCD, density and biomass of red hind increased $60 \%$ on average, whereas peak spawning densities more than doubled during a 3 yr period (Years 2000 to 2003). These values were supported by the fish trap catch rates which more than doubled after the MCD was established. Annual fluctuations in density were also apparent. The density of red hind peaked in both 2001 and 2003 but declined in the intervening years 2002 and 2004 (Fig. 3). Olsen \& LaPlace (1978) and Sylvester et al. (1978) recorded a similar phenomenon, whereby the St. Thomas red hind spawning aggregation showed high abundances based on catch rates in both 1975 and 1977 spawning seasons, extremely low abundance during the 1976 spawning season and moderate abundance in the 1978 season. Olsen \& LaPlace (1978) suggested that these changes in abundance were the result of both fishing mortality and the relocation of the spawning aggregation due to heavy fishing pressure and possibly subsequent predation pressure by sharks. The drop in density in 2002 and 2004 also followed increased catch-and-release fishing activity from my research in 2001 and 2003, but diver surveys and catch rates verified that the primary site of the spawning aggregation still had the highest densities and did not shift to a different location. Alternatively, this pattern may suggest a biannual difference in spawning cohort strength (odd years being the strong cohort), a phenomenon that is well-documented for some species of Pacific salmon (Bond 1996). The density of red hind during these peak spawning seasons in 2001 (January $=23.8$ fish $100 \mathrm{~m}^{-2}$ and February = 28.9 fish $100 \mathrm{~m}^{-2}$ ) and 2003 $\left(\right.$ January $=39.72$ fish $100 \mathrm{~m}^{-2}$ ) were the highest densities ever documented for a red hind spawning aggregation in the Caribbean. The average density of spawning red hind over the entire spawning area was $11.88,14.91,10.00,27.08$ and 19.31 red hind $100 \mathrm{~m}^{-2}$ for January 2000, 2001, 2002, 2003 and 2004, respectively. In 1984, Shapiro et al. (1993) recorded a peak density of 7.6 fish $100 \mathrm{~m}^{-2}$ with a mean of 3.8 fish $100 \mathrm{~m}^{-2}$ from a small red hind aggregation in SW Puerto Rico. The mean value for the Puerto Rico site is similar to the 4.7 fish $100 \mathrm{~m}^{-2}$ reported from the St. Thomas MCD in 1997 (Beets \& Friedlander 1999). However, the average density from the unprotected spawning aggregation in Puerto Rico dropped to 0.88 fish $100 \mathrm{~m}^{-2} 2 \mathrm{yr}$ later (Shapiro et al. 1993), whereas the average density of the St. Thomas MCD had increased to 11.88 fish $100 \mathrm{~m}^{-2} 3 \mathrm{yr}$ later. This suggests that the heavily overfished St. Thomas spawning population was still in a state of recovery in 1997 and that continued protection from fishing mortality had been extremely beneficial to the population.

During the last $3 \mathrm{yr}$ of seasonal closure, from 1997 (Beets \& Friedlander 1999) to 2000, the average length of the spawning population showed a significant increase from 36.6 to $38.8 \mathrm{~cm}$, or about $0.73 \mathrm{~cm} \mathrm{yr}^{-1}$. Although Beets \& Friedlander (1999) used traps with smaller mesh $\left(3.8 \mathrm{~cm}^{2}\right.$ vs. $\left.5.1 \mathrm{~cm}^{2}\right)$, it probably did not influence the results, since red hind caught in both studies were all greater than $25 \mathrm{~cm}$ in total length. Most red hind smaller than $25 \mathrm{~cm}$ are not yet reproductively active (Sadovy et al. 1992) and would not have entered the spawning aggregation. In the years following the MCD closure, the average size of red hind actually decreased by $0.9 \mathrm{~cm}$ (from 38.8 to $37.9 \mathrm{~cm}$ ) relative to the first year of sampling (Fig. 5). The decrease in average fish length may have been an artifact of sampling or a real change in the spawning population. Fish collected by hand line were $0.8 \mathrm{~cm}$ larger than fish caught with traps. Since the proportion of red hind caught by hand line decreased from $78.5 \%$ in 2000 to $11.5 \%$ in 2003 (Table 1) this size-related gear bias may have contributed to the $0.9 \mathrm{~cm}$ decline in average fish length during this period (Fig. 5). Alternatively, the decrease in fish length could have been effected by recruitment of small young females into the spawning population in 2003 (Fig. 8). A final alternative is that both gear bias and recruitment could have contributed to the slight decline in fish size from 2000 to 2003.

Beets \& Friedlander (1999) calculated that the area utilized by the red hind aggregation in 1997 was between 0.1 to $0.24 \mathrm{~km}^{2}$, the latter being comparable to the area calculated by the surveys in January 2000 and $2001\left(0.24 \mathrm{~km}^{2}\right)$. Based on these calculations, total spawning population size ranged between 4700 to 11280 fish in 1997 compared to 26229 red hind in 2000, 38143 in 2001 and an astonishing 84000 in 2003. The dramatic increase in the estimated population size 
of the red hind aggregation in 2003 resulted from both a westward expansion of the spawning aggregation and an increase in red hind density throughout this area. Prior to this study, most red hind spawning aggregations were thought to be small, ranging in size from 750 to 3000 fish (Shapiro 1987, Shapiro et al. 1993, Levin \& Grimes 2002) and occupying a spawning area of $0.01 \mathrm{~km}^{2}$. These early estimates were based on heavily fished aggregations in Puerto Rico. The population size estimates documented for the marine protected area in St. Thomas far exceed these values and begin to rival species such as Nassau grouper, for which up to 30000 individuals have been reported in a single aggregation (Smith 1972).

One explanation for the dramatic increase in red hind density after establishment of the MCD is that the efficiency of the fishery to catch red hind had been substantially decreased. Prior to the year-round closure in December 1999, fishermen could begin fishing within the MCD immediately following the closed spawning season which lasted from December through February. Based on the telemetry data, fish departing the spawning site most probably follow the relatively narrow $(<200 \mathrm{~m})$ coral reef ridges to the west and east, which afford groupers shelter from predation, before dispersing to their home sites. Strategic placement of traps along these migratory pathways may have had a significant impact on the spawning population as they departed the spawning site (Johannes 1981). Once fish dispersed from the spawning aggregation, the efficiency of fishing gear to capture large numbers of red hind was reduced, resulting in greater escapement from the commercial fishery. The year-round closure and the relatively large size of the MCD eliminated a potential fishing mortality bottleneck by allowing red hind to depart the aggregation in relative safety before dispersing to areas outside the reserve boundaries. Based on the tag-recapture data, the majority of red hind traveled about $15 \mathrm{~km}$ northwest to a rocky reef area around Sail Rock, St. Thomas (Fig. 1). Other fish were recaptured from $6 \mathrm{~km}$ to at least $33 \mathrm{~km}$ from the aggregation site, creating a source population area of at least $500 \mathrm{~km}^{2}$. These migration distances are comparable, if slightly higher, than those reported for red hind in SW Puerto Rico which dispersed 10 to $18 \mathrm{~km}$ from the spawning aggregation (Colin et al. 1987, Sadovy et al. 1992).

Another alternative is that the spawning aggregation may be composed largely of fish resident in the closed area, which now offers continued protection of red hind that remain on the shelf-edge reefs. Several studies in Puerto Rico found that red hind females migrate to shallower inshore areas, while males remain on the deeper offshore reefs (Shapiro 1987, Sadovy et al. 1994b). Commercial fishing on the deep offshore reefs after the seasonal closure ended may have had a proportionally greater impact on male red hind relative to females, which dispersed over wider areas. However, Nemeth \& Quandt (2004) found that, between the months of March and September, red hind densities on coral reef sites within the MCD $(\mathrm{n}=8)$ were lower than at non-MCD $(n=8)$ sites $(0.24$ vs. 0.42 red hind $100 \mathrm{~m}^{2}$, respectively). At this time it is unknown what proportion of the spawning population remains in non-coral reef habitats within the boundaries of the MCD. However, it is interesting that many tagged red hind were caught in a coral reef area within $6 \mathrm{~km}$ of the northwestern edge of the MCD. Of these fish, 3 were recaptured only $1.5 \mathrm{~km}$ outside the northwest corner of the MCD. This coral reef area extends into the MCD and may provide suitable habitat for red hind departing the spawning aggregation.

A final alternative to explain the significant increase in density, especially in 2003, is that a large cohort of young females recruited into the spawning population (Fig. 8). Sadovy et al. (1992) estimated that red hind from the St. Thomas region can grow to nearly $20 \mathrm{~cm}$ within 12 to 15 mo post-settlement and that up to $50 \%$ of red hind females within a population can reach sexual maturity within 3 yr. Growth rates in this study (1.2 to $4.8 \mathrm{~cm} \mathrm{yr}^{-1}$ ) were similar to rates for red hind in Puerto Rico (1.2 to $9.6 \mathrm{~cm} \mathrm{yr}^{-1}$, Sadovy et al. 1992). A cohort of young females could theoretically have been the result of increased reproductive output of the St. Thomas red hind aggregation during the Year 2000 spawning season. The larger size and number of red hind within this spawning population represents a substantial increase in fecundity over previous years. The estimated egg production for red hind females at $36 \mathrm{~cm}$ (i.e. mean size of females in St. Thomas) could produce over 500000 eggs female ${ }^{-1}$, and older, larger females that reach $40 \mathrm{~cm}$ in length can produce over 1000000 eggs (Olsen \& LaPlace 1978, Thompson \& Munro 1978, Sadovy et al. 1992, Whiteman et al. 2005). With the greatly increased reproductive output of females, subsequent larval recruitment and rapid growth rates of juveniles, one could expect larger cohorts of young females to enter the St. Thomas spawning aggregation in future years if self-recruiting occurs. Substantial increases in reproductive output is a major benefit of protected spawning populations of fish and invertebrates (Bohnsack 1992, Palsson \& Pacunski 1995, Kelly et al. 2000, Roberts et al. 2001, Gell \& Roberts 2003, Willis et al. 2003).

Protection of the St. Thomas red hind spawning aggregation seems to have had positive effects on the red hind population around St. Thomas. Based on a review of the literature and biostatistical data from port landings, the average length of red hind from the commercial catch has steadily increased and tracked the 
average length of the spawning population (Fig. 5). The lengths of red hind from commercial landings were typically smaller than catches from the spawning aggregation, since the commercial catch includes subadult fish from inshore waters which tend to be smaller (Olsen \& LaPlace 1978, Shapiro et al. 1993). The predominant factor affecting the size and abundance of groupers among diverse areas in the Caribbean is fishing pressure (Sluka et al. 1997, Chiappone et al. 2000). Thompson \& Munro (1978) reported that the mean size of red hind in intensely fished nearshore areas of Jamaica versus offshore oceanic banks was 26 and $33 \mathrm{~cm} \mathrm{TL}$, respectively. With a reduction in fishing pressure of the red hind spawning aggregation in St. Thomas, the average size of red hind at the spawning aggregation steadily increased from a low of $29.5 \mathrm{~cm}$ in 1988 (Beets \& Friedlander 1999) to nearly $39 \mathrm{~cm} 12 \mathrm{yr}$ later (this study, Fig. 5). A concurrent increase in length of the red hind population outside the aggregation was clearly evident and increased significantly after the MCD was established (Fig. 5). Interviews with commercial and recreational fishermen around St. Thomas by the author during the past several years highlighted a general perception that the red hind being caught now are larger than before the MCD was established.

The results reported in this paper indicate that seasonal protection of the red hind spawning aggregation allowed the spawning population to rebound relatively rapidly from overfishing in terms of size, density and sex ratios. Permanent protection of large areas surrounding the spawning habitat provided additional benefits toward increasing spawning stock density and biomass as well as maintaining sex ratios between 3 and 5 females per male (Whiteman et al. 2005). Other factors which may have contributed to these changes include change in fishing effort or gear and the implementation of other fishery regulations. The number of licensed commercial fishermen in the Virgin Islands has been stable for over $15 \mathrm{yr}$ (Tobias 1997, B. Kojis pers. comm.), whereas effort in trap-fishing doubled in St. Thomas from 1985 to 1996 (unpubl. data from NMFS biostatistical database). This increase in effort has apparently not influenced the red hind population. Between 1997 and 1999 fish traps with $3.8 \mathrm{~cm}^{2}$ $\left(1.5 \mathrm{inch}^{2}\right)$ square mesh were phased-out in St. Thomas (but not St. Croix) and replaced by traps with $5.1 \mathrm{~cm}^{2}$ $\left(2.0\right.$ inch $\left.^{2}\right)$ square mesh. This change may have increased escapement of smaller red hind, but the effect on the larger sized fish comprising the spawning population was probably minor, as evidenced by the lack of difference in minimum-sized fish caught by traps used in Beets \& Friedlander (1999) and this study. St. Croix also has a red hind spawning aggregation that has been seasonally protected since 1995. The sizes of red hind in the spawning aggregation and in the commercial catch have been declining and are considerably smaller ( 32.3 and $27.6 \mathrm{~cm}$, respectively) than red hind in the St. Thomas region (Nemeth unpubl. data). These factors suggest that the establishment of the MCD has been the primary stimulant for maintaining and improving the St. Thomas red hind spawning population, a finding which corroborates many studies on the benefits of using marine fishery reserves (MFR) as a management strategy (Pauly 1979, Roberts \& Polunin 1991, 1993, Russ 1991, Roberts 1995, Bohnsack 1996, Gell \& Roberts 2003).

Because red hind spawn in smaller social groups ( 3 to 5 fish $^{-1}$ group) than the large social groups of 1000 s to 10000 s of fish formed by other species like Nassau groupers Epinephelus striatus (Smith 1972, Olsen \& LaPlace 1978), it is likely that red hind spawning populations are impacted less by short-term fishing pressure (Colin et al. 1987) and may show more rapid recovery once fishing is reduced. After the collapse of the Nassau grouper fishery in Virgin Islands (Olsen \& LaPlace 1978) the red hind became the dominant grouper in the local fishery (Cummings et al. 1997). The change in catch composition from larger to smaller individuals and/or larger species being replaced by smaller species is well-documented (Luckhurst 1996, Chiappone et al. 2000). While Nassau grouper reach 850 to $950 \mathrm{~mm}$ (Olsen \& LaPlace 1978, Colin et al. 1987, Colin 1992), red hind reach maximum lengths around 500 to $550 \mathrm{~mm}$ (Olsen \& LaPlace 1978, Thompson \& Munro 1978, Colin et al. 1987, Sadovy et al. 1992), although specimens from 620 to $720 \mathrm{~mm}$ have been recorded (Smith 1971, Randall 1983, Luckhurst et al. 1992). Whether the Nassau grouper will be able to reclaim its historical spawning site within the $\mathrm{MCD}$ (Olsen \& LaPlace 1978) will require long-term monitoring efforts.

Other behavioral aspects of fish within spawning aggregations may also influence effects of differential fishing mortality. For example, males of many grouper species, including red hind, remain higher in the water column defending spawning territories or displaying to potential mates (Colin et al. 1987, Gillmore \& Jones 1992). Sex and/or size-selective fishing mortality in spawning aggregations will occur when these more behaviorally dominant males take baited hooks more frequently than females (Gillmore \& Jones 1992, Levin \& Grimes 2002). Moreover, Levin \& Grimes (2002) suggested that sex-changing female groupers of exploited populations may adopt stereotypical male behavior during the spawning season, making them more vulnerable to fishing and further disrupting reproduction.

Another example of the influence of behavior includes gender-biased small-scale movement patterns of aggregating groupers during the spawning season. 
My data suggest that male red hind arrive early at the spawning aggregation site (i.e. December) and stay on-site between spawning peaks. Thus, short-term seasonal closures, from 1 to $2 \mathrm{mo}$, that protect only the primary spawning month may make a large portion of the spawning population, especially males, vulnerable to fishing mortality. Between spawning peaks, a substantial portion (50 to $80 \%$ ) of red hind disperses short distances (at least $100 \mathrm{~m}$ ) into adjacent habitats (see Fig. 9). Size-frequency analysis suggests that most of these fish are probably females (fish $<40 \mathrm{~cm} \mathrm{TL}$ ). However, it is unknown what proportion of these fish seen in adjacent habitats were from the same group of spawning individuals that dispersed temporarily between full moon spawning events versus new arrivals waiting for the next full moon spawning event. If red hind and other larger grouper species disperse considerable distances between spawning peaks, then the size and placement of MPA boundaries may not provide sufficient protection from fishing if fish disperse beyond MPA boundaries during the spawning season. These findings suggest that the design of marine fishery reserves must take into account not only critical fish habitats but also the important life-history attributes that may exacerbate fishing mortality effects on protogynous species.

In the light of my findings, the potential economic and conservation benefits of establishing the Red Hind Bank Marine Conservation District to the Virgin Islands are becoming evident. Continued protection of the red hind spawning aggregation will mean greater reproductive output for this species and better catches in the near future for commercial fishermen of the Virgin Islands and eastern Puerto Rico. Most importantly, interviews with commercial and recreational fishermen indicate that a noticeable increase in the size and abundance of red hind has occurred over the past few years. The perception that the MCD is enhancing the local fishery may facilitate a positive change in social attitude and behavior toward the acceptance of marine fisheries reserves (Roberts 2001) and highlight the regional fishery benefits associated with protecting spawning aggregations.

Acknowledgements. This research was supported by research grants to R. Nemeth from NOAA/NMFS MARFIN program (NA97FF0348), National Fish and Wildlife Foundation (399-210), Puerto Rico Sea Grant Program (R-101-1-02) and National Institute of Health MBRS-SCORE (1 S06 GM066923-01). This work could not have been conducted without the help of research divers A. Quandt, L. Requa, S. Herzlieb, S. Kadison, E. Whiteman and J. Blondeau. Special thanks to K. Turbe for his fishing expertise and knowledge, to the US Virgin Islands Division of Fish and Wildlife for use of equipment, and to C. Jennings for technical guidance. I greatly appreciate the cooperation and vessel support of commercial fishers K. Campbell and E. Bryan and his crew of the 'Feel Good II'. Thanks to the fishermen who participated in the tag-reward program by returning tags. Critical reviews by E. Whiteman and 3 anonymous reviewers greatly improved this manuscript. Finally, the author is grateful for the biostatistical data provided by the National Marine Fisheries Service and the Virgin Islands Division of Fish and Wildlife.

\section{LITERATURE CITED}

Aguilar-Perera A, Aguilar-Davila W (1996) A spawning aggregation of Nassau grouper Epinephelus striatus (Pisces: Serranidae) in the Mexican Caribbean. Environ Biol Fish 45:351-361

Alcala AC (1988) Effects of marine reserves on coral fish abundance's and yields of Phillipine coral reefs. Ambio 17: 194-199

Allison G, Lubchenco J, Carr MH (1998) Marine reserves are necessary but not sufficient for marine conservation. Ecol Appl 8:S79-S92

Appeldoorn RS, Lindeman KC (2003) A Caribbean-wide survey of marine reserves: spatial coverage and attributes of effectiveness. Gulf Caribb Res 14:139-154

Beets J, Friedlander A (1992) Stock analysis and management strategies for red hind, Epinephelus guttatus, in the U.S. V. I. Proc 42nd Gulf Caribb Fish Inst 42:66-79

Beets J, Friedlander A (1997) Evaluation of the spawning aggregation closure for red hind (Epinephelus guttatus), St. Thomas, US Virgin Islands. Caribbean Fisheries Management Council, San Juan, p 17

Beets J, Friedlander A (1999) Evaluation of a conservation strategy: a spawning aggregation closure for red hind, Epinephelus guttatus, in the US Virgin Islands. Environ Biol Fish 55:91-98

Bohnsack JA (1992) Reef resource habitat protection: the forgotten factor. Mar Recreational Fish 14:117-129

Bohnsack JA (1996) Maintenance and recovery of reef fishery productivity. In: Roberts C (ed) Reef fisheries. Chapman and Hall, London, p 283-313

Bohnsack JA (1998) Application of marine reserves to reef fisheries management. Austr J Ecol 23:298-304

Bohnsack JA (2000) A comparison of short-term impacts of no-take marine reserves and minimum size limits. Bull Mar Sci 66:635-650

Bohnsack JA, Harper DE (1988) Length-weight relationships of selected marine reef fishes from the southeastern United States and the Caribbean. NOAA Tech Memo NMFS-SEFC-215:31

Bohnsack JA, Sutherland D, Brown A, Harper D, McClellan D (1986) An analysis of the Caribbean biostatistical database for 1985. Contribution No. CRD-86/87, NMFS-SEFC, US Department of Commerce Coastal Resources Division, Miami, FL, p 10

Bond CE (1996) Biology of fishes, 2nd edn. Brooks/Cole, Pacific Grove, CA

Chiappone M, Sluka R, Sealey KS (2000) Groupers (Pisces: Serranidae) in fished and protected areas of the Florida Keys, Bahamas and northern Caribbean. Mar Ecol Prog Ser 198:261-272

Claro R, Lindeman KC (2003) Spawning aggregation sites of snapper and grouper species (Lutjanidae and Serranidae) on the insular shelf of Cuba. Gulf Caribb Res 14:91-106

Claro R, Baisre JA, Lindeman KC, Garcia-Arteaga (2001) Cuban fisheries: historical trends and current status. In: Parenti LR (ed) Ecology of the marine fishes of Cuba. Smithsonian Institution, Washington, DC, p 194-219

Clavijo IE, Tobias WJ (1985) Virgin Islands commercial fish- 
eries research and development project. April 1, 1984 to March 31 1985. Annual Report PL 88-309. Project No. 2-411-R-1, National Marine Fisheries Service, St. Petersburg, FL, p 15

Clavijo IE, Tobias WJ, Jennings CA (1986) Virgin Islands commercial fisheries research and development project. April 1, 1985 to March 31 1986. Annual report Project No. 2-411-R-2, PL 88-309, National Marine Fisheries Service, St. Petersburg, FL, p 15

Colin PL (1992) Reproduction of Nassau grouper, Epinephelus striatus (Pisces: Labroidei) and its relationship to environmental conditions. Environ Biol Fish 34:357-377

Colin PL, Shapiro DY, Weiler D (1987) Aspects of the reproduction of two groupers, Epinephelus guttatus and E. straitus in the West Indies. Bull Mar Sci 40:220-230

Council Caribbean Fisheries Management (CFM) (1985) Fishery management plan: final environmental impact statement and draft regulatory impact review for the shallow-water reef fish fishery of Puerto Rico and the US Virgin Islands. Report No. PL-94-265 (MFCMA), National Marine Fisheries Service, San Juan, p 69

Cummings NJ, Parrack ML, Zweifel JW (1997) The status of red hind and coney in the U.S. Virgin Islands between 1974 and 1992. Proc 49th Gulf Caribb Fish Inst, 49:354-397

Domeier ML, Colin PL (1997) Tropical reef fish spawning aggregations: defined and reviewed. Bull Mar Sci 60: 698-726

Gell FR, Roberts CM (2003) Benefits beyond boundaries: the fishery effects of marine reserves. Trends Ecol Evol 18: 448-455

Gillmore RG, Jones RS (1992) Color variation and associated behaviors in the Epinepheline groupers, Myteroperca microlepis (Goode and Bam) and M. phenax (Jordan and Swain). Bull Mar Sci 51:84-103

Halpern BS (2003) The impact of marine reserves: Do reserves work and does reserve size matter? Ecol Appl 13: S117-S137

Halpern BS, Warner RR (2002) Marine reserves have rapid and lasting effects. Ecology 5:361-366

Heyman WD, Graham RT, Kjerfve B, Johannes RE (2001) Whale sharks Rhincodon typus aggregate to feed on fish spawn in Belize. Mar Ecol Prog Ser 215:275-282

Johannes RE (1978) Reproductive strategies of coastal marine fishes in the tropics. Envir Biol Fish 3:65-84

Johannes RE (1981) Words of the lagoon. Fishing marine lore in the Palau district of Micronesia. University of California, Los Angeles

Johannes RE (1989) Spawning aggregations of the grouper, Plectropomus areolatus (Ruppel) in the Solomon Islands. Proc 6th Int Coral Reef Symp 2:751-755

Kelly S, Scott D, MacDiarmid AB, Babcock RC (2000) Spiny lobster, Jasus edwardsii recovery in New Zealand marine reserves. Biol Conserv 92:359-369

Kramer DL, Chapman MR (1999) Implications of fish home range size and relocation for marine reserve function. Environ Biol Fish 55:65-79

Levin PS, Grimes CB (2002) Reef fish ecology and grouper conservation and management. In: Sale PF (ed) Coral reef fishes, dynamics and diversity in a complex ecosystem. Academic Press, New York, p 377-390

Lindeman KC, Pugliese R, Waugh GT, Ault JS (2000) Developmental patterns within a multispecies reef fishery: management applications for essential fish habitats and protected areas. Bull Mar Sci 33:929-956

Luckhurst BE (1996) Trends in commercial fishery landings of groupers and snappers in Bermuda from 1975 to 1992 and associated fishery management issues. In: Pauly D (ed) Biology, fisheries and culture of tropical groupers and snappers. International Center for Living Aquatic Resources Management (ICLARM), Manila, p 277-288

Luckhurst BE, Barnes J, Sadovy Y (1992) Record of an unusually large red hind, Epinephelus guttatus (Serranidae), from Bermuda with comments on its age. Bull Mar Sci 51: 267-270

McClanahan TR, Kaunda-Arara B (1996) Fishery recovery in a coral-reef marine park and its effects on the adjacent fishery. Conserv Biol 10:1187-1199

McClanahan TR, Mangi S (2000) Spillover of exploitable fishes from a marine park and its effects on the adjacent fishery. Ecol Appl 10:1792-1805

Morales-Santana I (1984) Report on the reef fish size frequency survey July-September, 1983, Caribbean Fisheries Management Council, San Juan, p 18

Munro JL (1996) The scope of tropical reef fisheries and their management. In: Roberts C (ed) Reef fisheries. Chapman Hall, London, p 1-14

Nemeth R, Quandt A (2004) Differences in fish assemblage structure following the establishment of the Marine Conservation District, St. Thomas US Virgin Islands. Proc 56th Gulf Caribb Fish Inst (in press)

Olsen DA, LaPlace JA (1978) A study of Virgin Islands grouper fishery based on a breeding aggregation, Proc 31st Gulf Caribb Fish Inst 31:130-144

Palsson WA, Pacunski RE (1995) The response of rocky reef fishes to harvest refugia in Puget Sound Puget Sound. Research '95, Wash Department of Fish and Wildlife, Olympia, WA

Pauly D (1979) Theory and management of tropical multi-species stocks: a review with emphasis on South East Asian demersal fisheries ICLARM Stud Rev 1:35

PDT (Plan Development Team) (1990) The potential of marine fishery reserves for reef fish management in the US Soutern Atlantic. Report No. NMFS-SEFC-261, NOAA, National Marine Fisheries Service, Miami, FL

Potts JC, Manooch CS (1995) Age and growth of red hind collected from North Carolina through the Dry Tortugas, Florida. Bull Mar Sci 56:784-795

Randall JE (1983) Caribbean reef fishes, 2nd. TFH, Neptune, NJ

Roberts CM (1995) Effects of fishing on the ecosystem structure of coral reefs. Conserv Biol 9:988-995

Roberts CM (1996) Settlement and beyond: population regulation and community structure of reef fishes. In: Roberts C (ed) Reef fisheries. Chapman \& Hall, London, p 85-112

Roberts CM (1997) Ecological advice for the global fisheries crisis. Trends Ecol Evol 12:35-38

Roberts CM, Polunin NVC (1991) Are marine reserves effective in management of marine fisheries? Rev Fish Biol Fish 1:65-91

Roberts CM, Polunin NVC (1993) Marine reserves: simple solutions to managing complex fisheries? Ambio 22: 363-368

Roberts CM, Bohnsack JA, Gell F, Hawkins PJ, Goodridge R (2001) Effects of marine reserves on adjacent fisheries. Science 294:1920-1923

Russ GR (1991) Coral reef fisheries: effects and yields. In: Sale PF (ed) The ecology of fishes on coral reefs. Academic, San Diego, CA, p 601-635

Sadovy Y (1994) Grouper stocks of the western Atlantic: the need for management and management needs. Proc 43rd Gulf Caribb Fish Inst, 43:43-65

Sadovy Y (1996) Reproduction in reef fishes. In: Roberts C (ed) Reef fisheries. Chapman \& Hall, London, p 15-59 
Sadovy Y, Figuerola M (1992) The status of red hind fishery in Puerto Rico and St. Thomas, as determined by yield-perrecruit analysis. Proc 42nd Gulf Caribb Fish Inst 42:23-38

Sadovy Y, Figuerola M, Roman A (1992) Age and growth of red hind, Epinephelus guttatus in Puerto Rico and St. Thomas. Fish Bull Fish Wildl Serv US 90:516-528

Sadovy Y, Colin PL, Domier ML (1994a) Aggregation and spawning in the tiger grouper, Mycteroperca tigris (Pisces: Serranidae). Copeia 2:511-516

Sadovy Y, Rosario A, Roman A (1994b) Reproduction in an aggregating grouper, the red hind, Epinephelus guttatus. Environ Biol Fish 41:269-286

Sala E, Ballesteros E, Starr RM (2001) Rapid decline of Nassau grouper spawning aggregations in Belize: fishery management and conservation needs. Fisheries 26:23-30

Shapiro DY (1987) Reproduction in groupers. In: Ralston S (ed) Tropical snappers and groupers: biology and fisheries management. Westview Press, Boulder, CO, p 295-328

Shapiro DY, Sadovy Y, McGehee MA (1993) Size, composition, and spatial structure of the annual spawning aggregation of the red hind, Epinephelus guttatus (Pisces: Serranidae). Copeia 2:399-406

Shapiro DY, Garcia-Moliner G, Sadovy Y (1994) Social system of an inshore population of the red hind grouper, Epinephelus guttatus (Pisces: Serranidae). Environ Biol Fish 41:415-422

Sluka R, Chiappone KM, Sullivan KM, Wright R (1997) The benefits of a marine fishery reserve for Nassau grouper

Editorial responsibility: Otto Kinne (Editor-in-Chief), Oldendorf/Luhe, Germany
Epinephelus striatus in the central Bahamas. Proc 8th Int Coral Reef Symp 2:1961-1964

Smith CL (1971) A revision of the American groupers: Epinephelus and allied genera. Bull Am Mus Nat Hist 146: 69-241

Smith CL (1972) A spawning aggregation of Nassau grouper Epinephelus striatus (Bloch). Trans Am Fish Soc 101: 257-261

Sylvester JR, LaPlace JA, Quetel R, Olsen DA, Dammann AE (1978) Life history and harvest of commercially caught Virgin Island's groupers for period 7/1/75-9/30/77. Completion report to Job II of PL 88-309, National Marine Fisheries Service, St. Petersburg, FL, p 24

Thompson R, Munro JL (1978) Aspects of the biology and ecology of Caribbean reef fishes: Serranidae (hinds and groupers). J Fish Biol 12:115-146

Tobias W (1997) Three year summary report: Cooperative Fishery Statistics Program. Report No. SF-42 (NA27FT0301-01), National Marine Fisheries Service, St. Petersburg, FL

Whiteman EA, Jennings CA, Nemeth RS (2005) Reproductive characteristics of a red hind (Epinephelus guttatus) spawning aggregation: applying ultrasound imaging for population assessment. J Fish Biol (in press)

Willis TJ, Millar RB, Babcock RC (2003) Protection of exploited fishes in temperate regions: high density and biomass of snapper Parus auratus (Sparidae) in northern New Zealand marine reserves. J Appl Ecol 40:214-227

Submitted: December 3, 2003; Accepted: August 24, 2004 Proofs received from author(s): December 27, 2004 